LA-10333-MS

SERI/PR-254-2028

UC-59B

Issued: May 1985

\title{
Solar Energy Research Institute Validation Test House Site Handbook
}

\author{
J. Burch* \\ D. Wortman* \\ R. Judkoff* \\ B. D. Hunn
}

\begin{abstract}
This work is a cooperative effort between the Los Alamos National Laboratory and the Solar Energy Research Institute.
\end{abstract}

*Solar Energy Research Institute, 1617 Cole Blvd., Golden, CO 80401

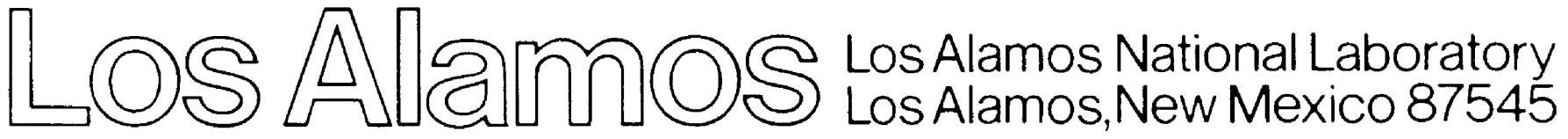


This work was supported by the US Department of Energy, Office of Solar Heat Technologies.

Prepared by Jan Sander and Miquela Sanchez, Group Q-13

DISCLAIMER

This report was prepared as an account of work sponsored by an agency of the United States Government. Neither the United States Government nor any agency thereof, nor any of their employees, makes any warranty, express or implied, or assumes any legal liability or responsibility for the accuracy, completeness, or usefulness of any information, apparatus, product, or process disclosed, or represents that its use would not infringe privately owned rights. Reference herein to any specific commercial product, process, or service by trade name, trademark, manufacturer, or otherwise, does not necessarily constitute or imply its endorsement, recommendation, or favoring by the United States Government or any agency thereof. The views and opinions of authors expressed herein do not necessarily state or reflect those of the United States Government or any agency thereof. 


\section{CONTENTS}

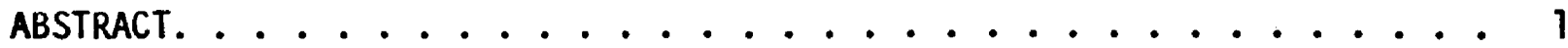

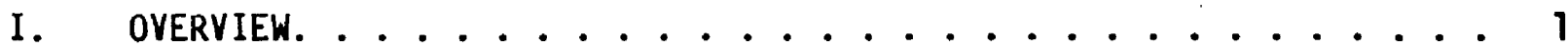

A. History and Purpose............... 1

B. The Building................. 2

C. Scope of this Handbook. .................. 3

II. DESCRIPTION OF THE ENVIRONMENT. .............. 4

III. DESCRIPTION OF THE TEST HOUSE ............... 6

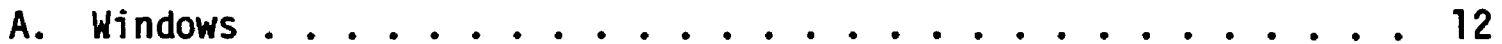

B. Doors ....................... 16

C. Description of Passive Solar and Conservation Features. . . . 16

D. Heating, Ventilating, and Air Conditioning (HVAC) System and Plant Description .............. 17

IV. DATA ACQUISITION AND TEST CONDITIONS. ........... 18

A. Description of Sensors. . ........... 18

B. Description of Data-Acqui sition System. ......... 20

C. One-Time and Special Measurements . . . . . . . . . 20

D. Hourly Data Tape. . . . . . . . . . . . . . 20

E. Test Conditions ................... 21

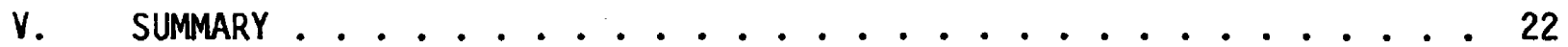

REFERENCES. ........................ 22

APPENDIX A. MATERIAL PROPERTIES. . . . . . . . . . . . 23

APPENDIX B. SENSOR LOCATION DIAGRAMS ............. 26

APPENDIX C. LIST OF DATA RECORDED HOURLY . . . . . . . . . 33 


\section{SOLAR ENERGY RESEARCH INSTITUTE \\ VALIDATION TEST HOUSE \\ SITE HANDBOOK}

by

J. Burch, D. Wortman, R. Judkoff, and B. D. Hunn

\section{ABSTRACT}

The Validation Test House at the Solar Energy Research Institute in Golden, Colorado, is being used to collect performance data for analysis/design tool validation as part of the DOE Passive Solar Class A Performance Evaluation Program. This site handbook describes in detail the construction, instrumentation, and test configuration of the building for use by passive solar analysis/design tool developers and researchers.

\section{OVERVIEN}

A. History and Purpose

The Solar Energy Research Institute (SERI) Validation Test House is located in Golden, Colorado, in Jefferson County. This test building has been established for Class A performance monitoring activities under the U.S. Department of Energy (DOE) Passive and Hybrid Solar Energy Program. The objective of the Class $A$ project is to obtain system and energy-transfer mechanism level data from which public-domain building energy analysis programs can be val idated and their accuracy assessed.

In 1980 this single-family detached residence, originally built in the early 1950s, was purchased by SERI for use in detailed monitoring of energy flows in buildings. It was moved to the site at the SERI outdoor test area and installed on footings poured to accommodate the building. The thermal integrity of the building envelope was then upgraded by insulating the attic, 
adding foam insulation to the wall cavities, extensive caulking, and adding storm doors and windows. Although not designed as a passive solar heated building, its large south-facing glazing makes it representative of many lowmass, direct-gain (sun tempered) residences. A photograph of the building is shown in Fig. 1.

B. The Building

The test site on which the building is located is at $39.7^{\circ} \mathrm{N}$ latitude, $105.20^{\circ} \mathrm{W}$ longitude, at an elevation of $1740 \mathrm{~m}(5710 \mathrm{ft})$ above sea level. Figure 2 shows the location of the building on the site and the topography of the immediate area.

A floor plan of the building in Fig. 3 shows this $93.6 \mathrm{~m}^{2}\left(1007 \mathrm{ft}^{2}\right)$ single-story, unoccupied residence to be of well-insulated frame construction. Its substantial south-facing glazing, coupled with a layer of brick pavers placed on the floor in the living/dining room and south bedroom to provide thermal-storage mass, creates a low-mass, direct-gain passive solar heating system.

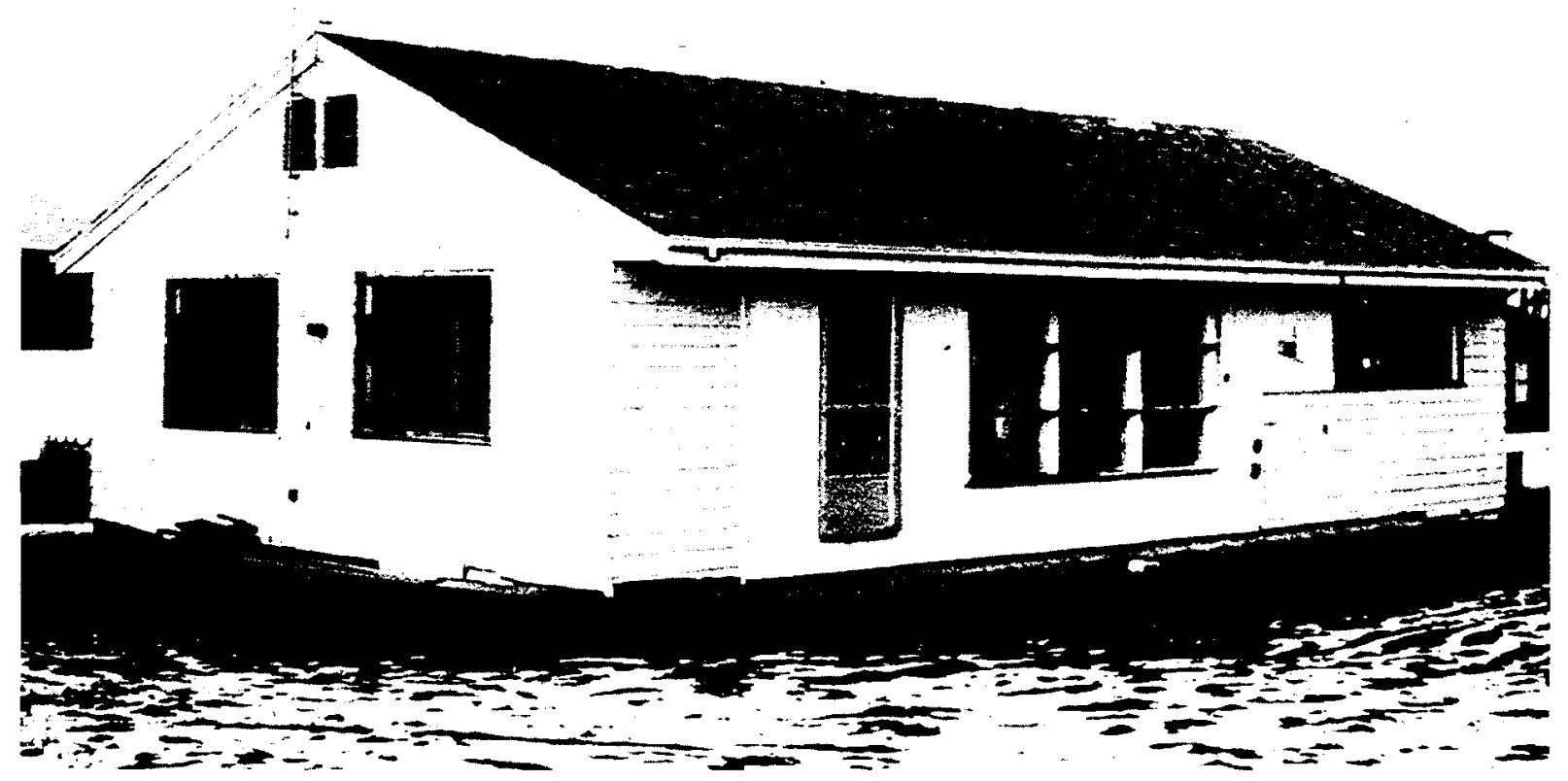

Fig. 1. SERI Validation Test House. 


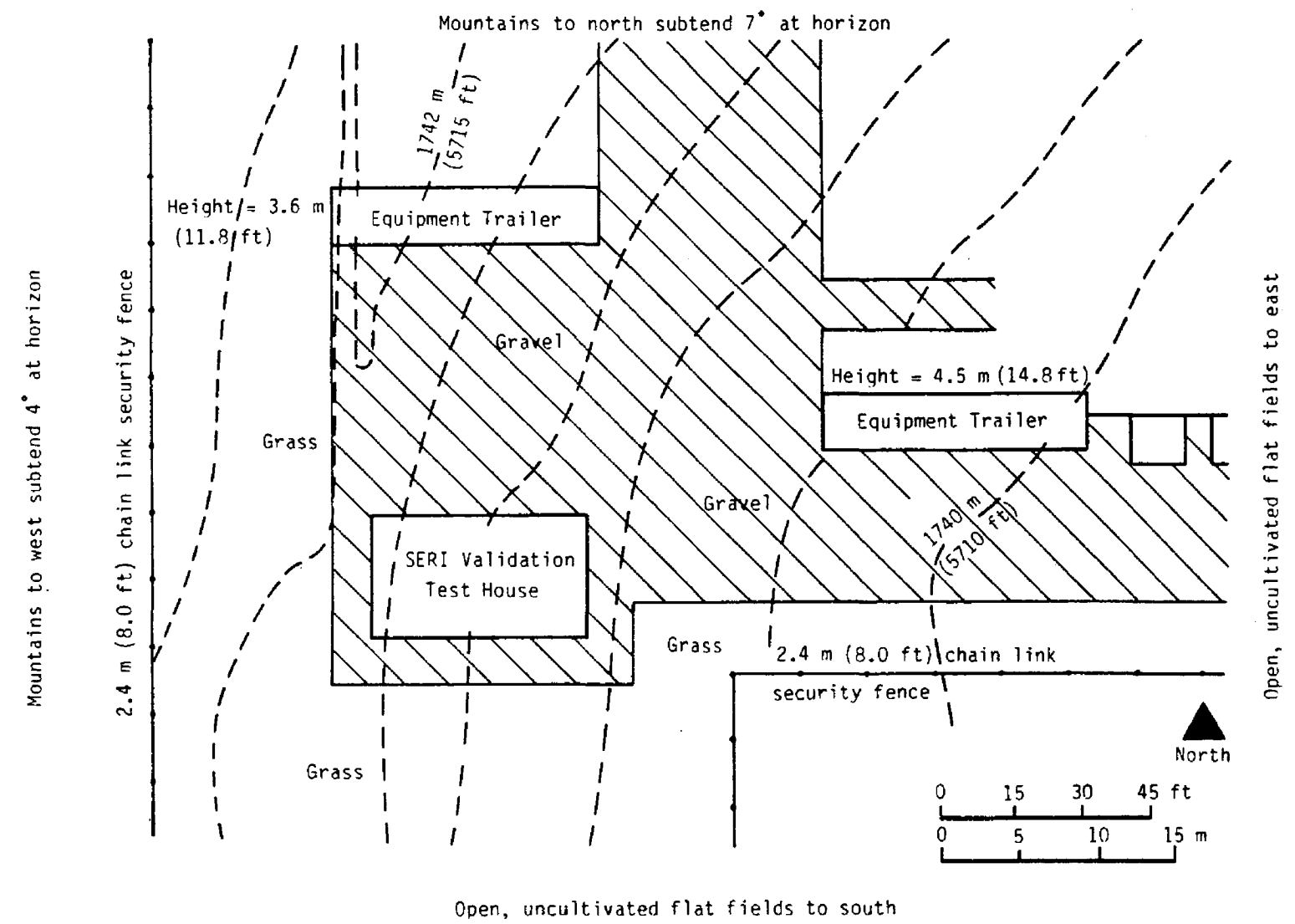

Fig. 2. Site plan of the SERI Validation Test House.

\section{Scope of this Handbook}

This handbook gives a complete physical description of the validation test house, and the results of one-time thermal/physical property and operating parameter measurements. These data are intended to provide sufficient information to prepare measurement-based inputs of building properties for any level of building energy simulation. Hourly experimental data (state points and energy flows) taken in the building will be available on magnetic tape. Sensor placements and a list of data taken during normal operation are pro$v$ ided in the Appendices. Additional information concerning the SERI test house may be obtained from:

Dr. Jay Burch/David Wortman, P.E.

Buil dings Research Branch, 15/3

Solar Energy Research Institute

1617 Cole Boulevard

Gol den, CO 80401

(303) $237-1453$ or 237-1095

(FTS) $327-1453$ or $327-1095$ 

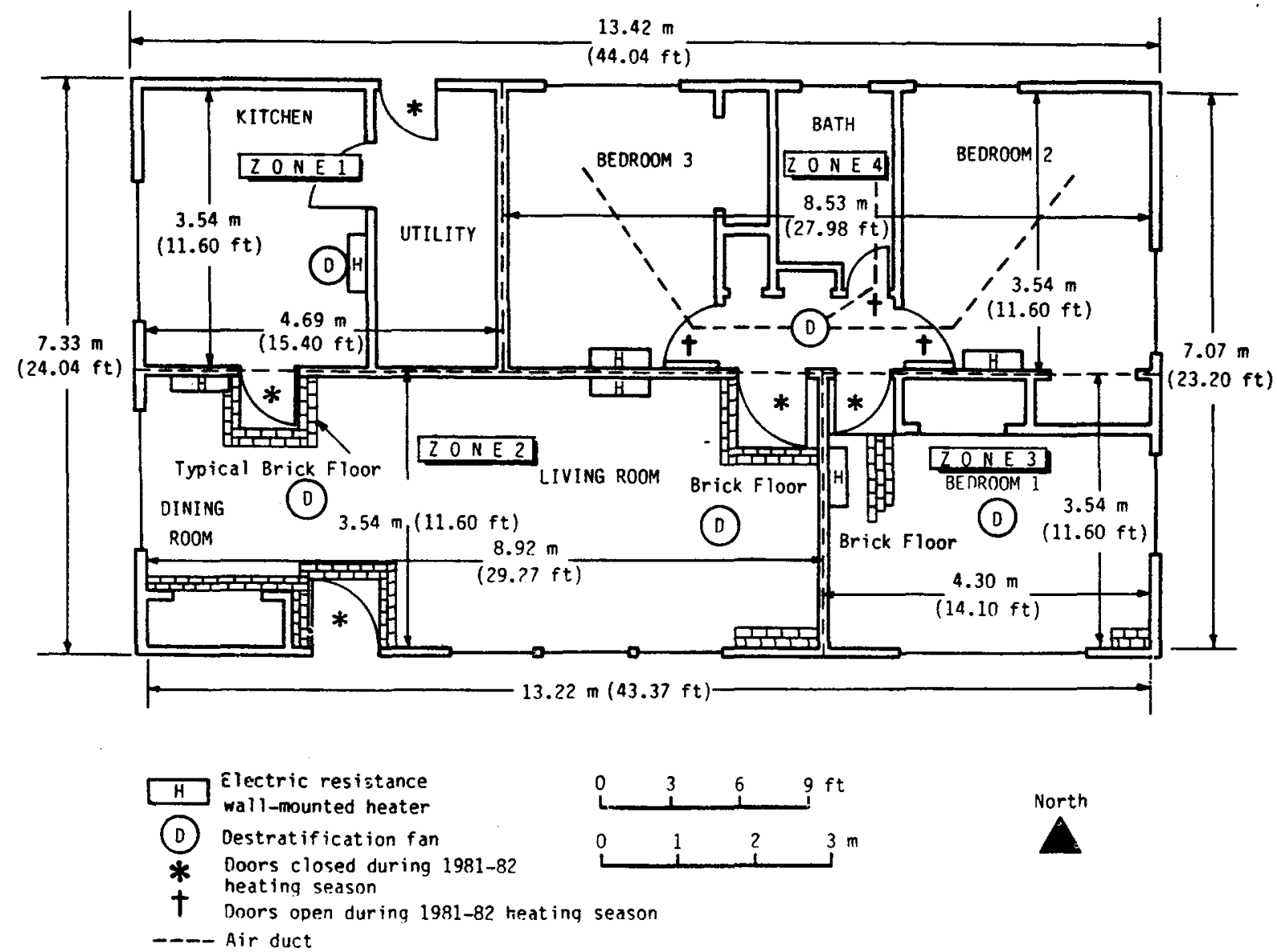

Fig. 3. Floor plan of SERI Validation Test House.

\section{DESCRIPTION OF THE ENYIROMMENT}

A site plan for the SERI Validation Test House is given in Fig. 2. The contour is generally ievel, with gravel (reflectance $\simeq 0.2$ ) imediately surrounding the entire building; during the winter, this area is sometimes covered with snow (reflectance $\approx 0.7$ ). There is rio significant shading effect from trees or other external objects. Mountains to the west and to the north subtend angles from the horizon of $4^{\circ}$ and $7^{\circ}$ on average, respectively.

The American Institute of Architects/Research Corporations (AIA/RC) regional climatic classification for Golden, Colorado, is type 3 (Great Plains, intermountain basin and plateaus). ${ }^{1}$ Local weather data are summarized in Tabie I; the nearest Typical Meteorological Year weather station is in Denver, Colorado. 


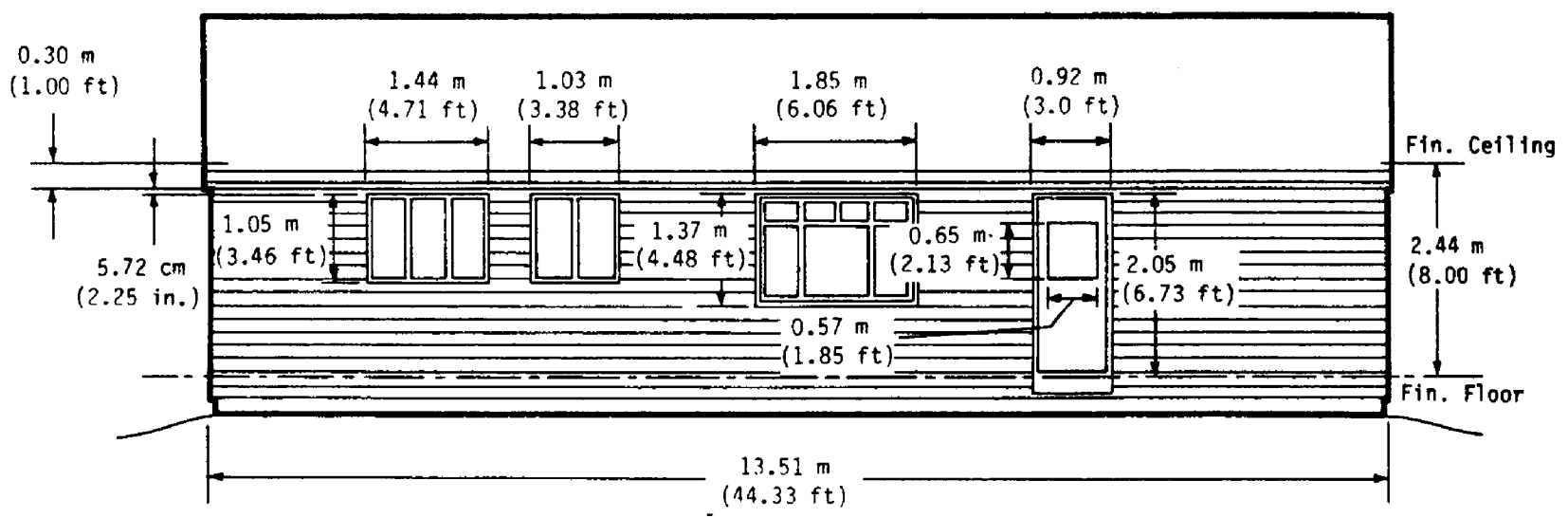

Fig. 4. North elevation.

TABLE I

LOCAL WEATHER DATA

$\begin{array}{ll}\text { Heating degree days } & 3634^{\circ} \mathrm{C} \text {-days }\left(6542^{\circ} \mathrm{F} \text {-days }\right) \\ \begin{array}{l}\text { Average winter temperature } \\ \text { (December - March) }\end{array} & 0.2^{\circ} \mathrm{C}\left(32.3^{\circ} \mathrm{F}\right) \\ \begin{array}{l}\text { Design dry-bulb temperature for heating } \\ \text { (97.5\% point) }\end{array} & -17.2^{\circ} \mathrm{C}\left(1^{\circ} \mathrm{F}\right)^{2} \\ \begin{array}{l}\text { Cooling degree days [base temperature } \\ 21.1^{\circ} \mathrm{C}\left(70^{\circ} \mathrm{F}\right) \text { ] }\end{array} & 286^{\circ} \mathrm{C} \text {-days }\left(515^{\circ} \mathrm{F} \text {-days }\right) \\ \begin{array}{l}\text { Design dry-buib and mean coincident } \\ \text { wet-bulb temperatures }(2.5 \% \text { point })\end{array} & 32.8^{\circ} \mathrm{C}\left(92^{\circ} \mathrm{F}\right) / 15^{\circ} \mathrm{C}\left(59^{\circ} \mathrm{F}\right)^{2} \\ \text { Average annual wind speed } & 14.5 \mathrm{~km} / \mathrm{h}(9.0 \mathrm{mph})-\text { medium } \\ \text { Prevailing wind direction } & \text { West* } \\ \text { Cloud cover } & \\ \text { December - March } & 51-58 \% \\ \text { April - November } & 41-58 \%\end{array}$

*Data from Rocky Flats, Colorado, $24 \mathrm{~km}(15 \mathrm{~m})$ north of the site. 
TABLE I (cont.)

Monthly Rain and Snowfall

January

February

March

April

May

June

July

August

September

october

November

December

Annual
Rain

$\frac{\mathrm{cm}}{1.2}$

1.5

2.8

5.1

$6 . ?$

3.8

4.3

3.6

2.8

2.5

1.7

$\frac{1.6}{37.0}$ $\frac{\text { in. }}{0.5}$

0.6

1.1

2.0

2.4

1.5

1.7

1.4

1.1

1.0

0.7

$\frac{0.6}{14.6}$
Snow

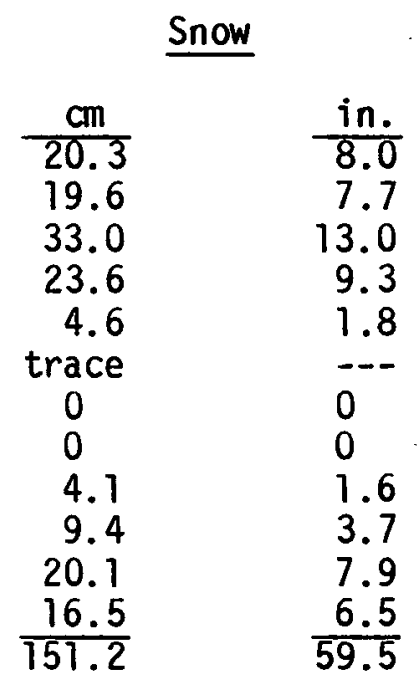

\section{DESCRIPTION OF THE TEST HOUSE}

The SERI Validation Test House is of 1 ight frame construction [2x6s and $2 \times 4 \mathrm{~s}$ on $0.41 \mathrm{~m}$ (16 in.) centers], with hardwood floors over a crawl space. After the building was moved to the site, it was heavily retrofitted with insulation and caulking, and storm windows were installed. To obtain greater storage mass for the direct-gain system, brick pavers were placed on the hardwood floors throughout virtually the entire south zones (Zones 2 and 3 ). North, south, east, and west elevations of the house are shown in Figs. 4-7.

For purposes of computer modeling, the building is divided into four zones separated by closed, sealed doors (Fig. 3); dimensioned floor plans for the zones are shown in Figs. 8-11, and areas and volumes are summarized in Table II. The kitchen and the utility room are Zone 1 (Fig. 8), the dining room-living room is Zone 2 (Fig. 9); Zone 3 is bedroom 1 (Fig. 10); and Zone 4 is comprised of the bathroom and bedrooms 2 and 3 (Fig. 11). Destratifiers were used in each zone, as shown in Fig. 3.

A description of the construction details and materials is given in Table III for each wall, floor, ceiling, and roof construction. A typical north/south building section is shown in Fig. 12 and a typical east/west section is shown in Fig. 13. Thermal and physical properties of construction materials are given in Appendix A. Four louvers, each with $0.093 \mathrm{~m}^{2}(1.00$ 


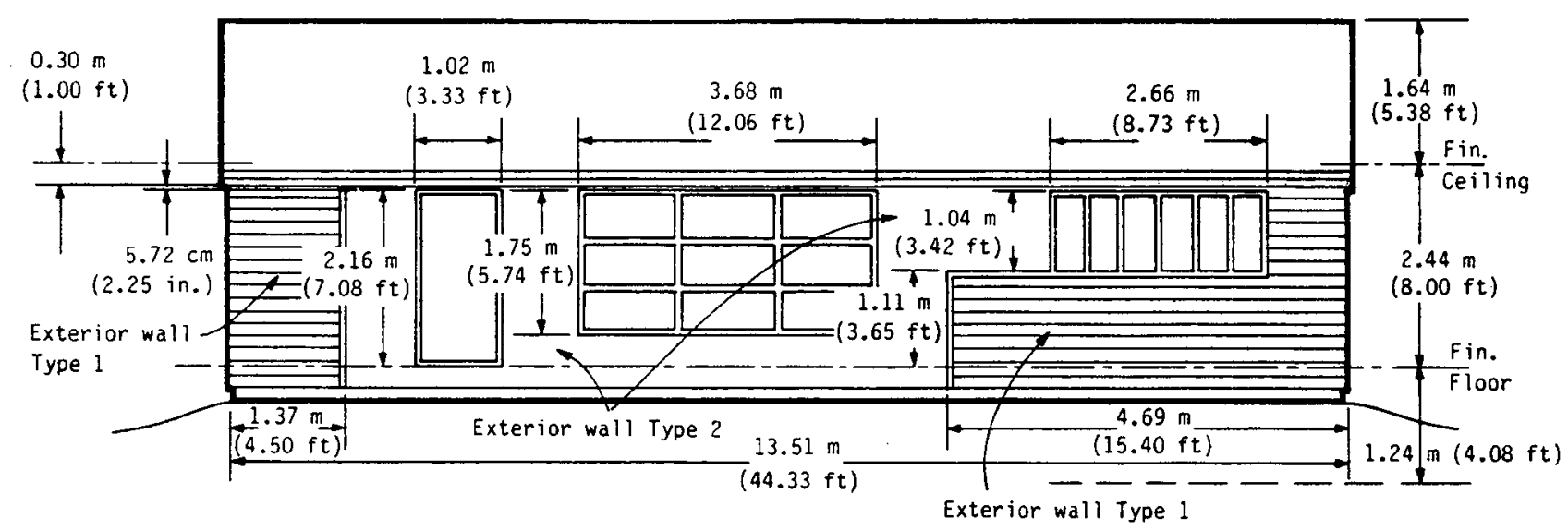

Fig. 5. South elevation.

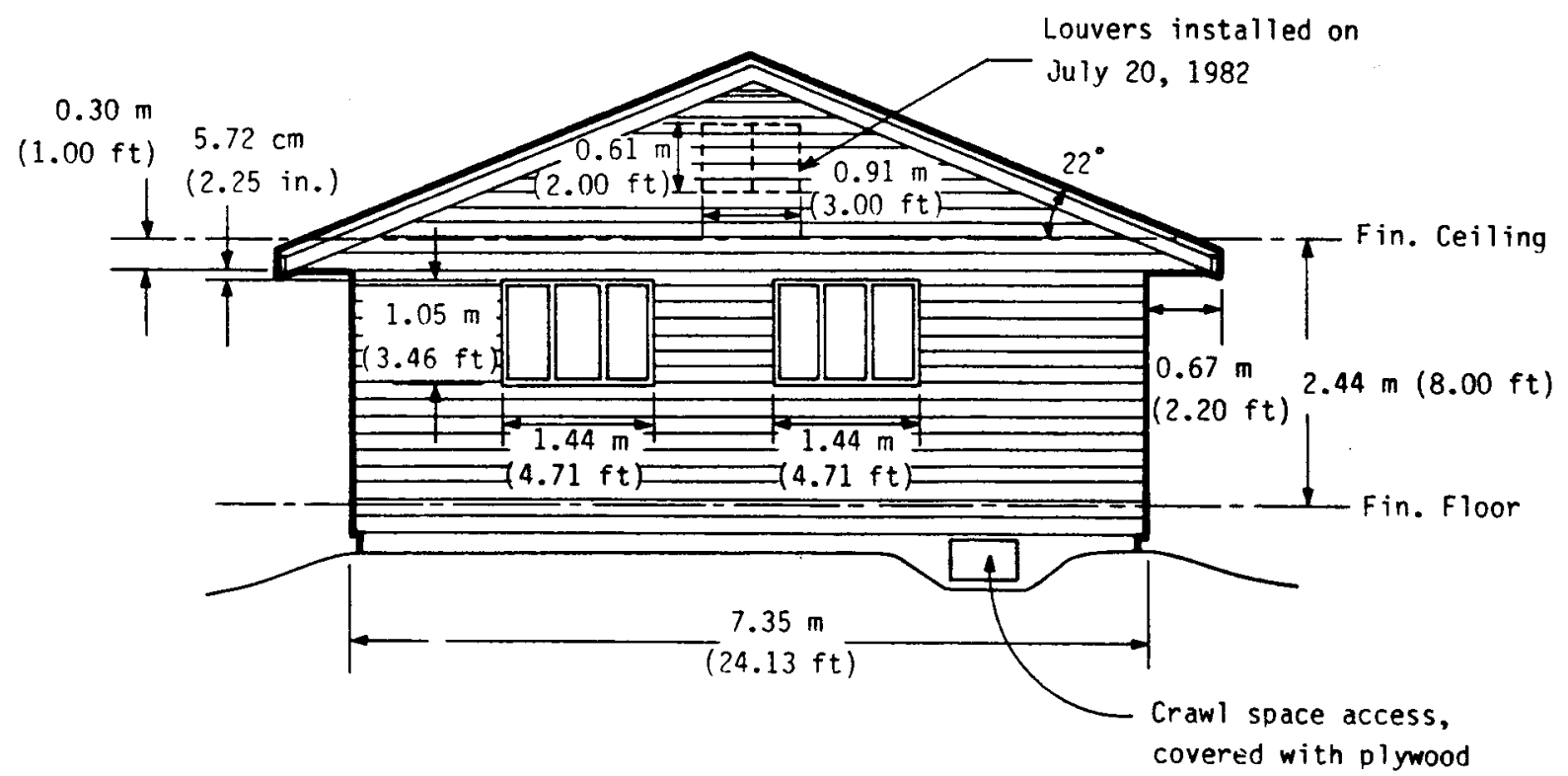

Fig. 6. East elevation.

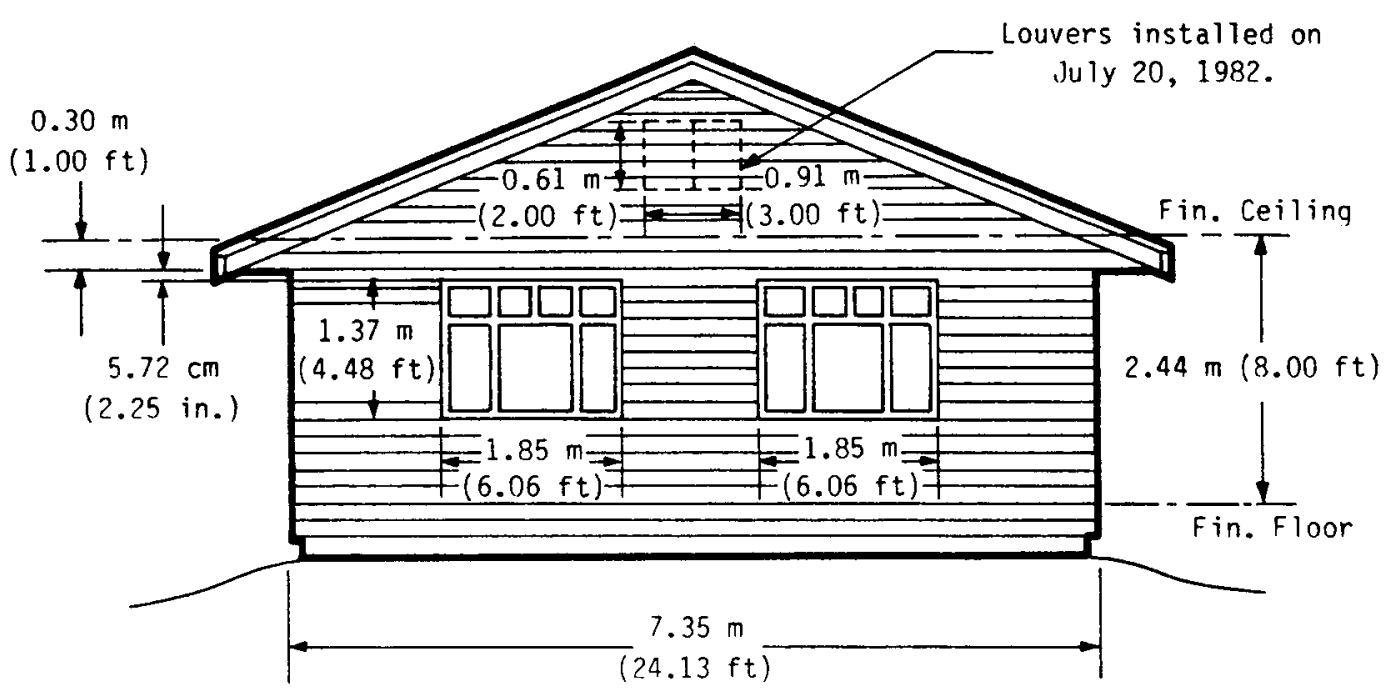

Fig. 7. West elevation. 


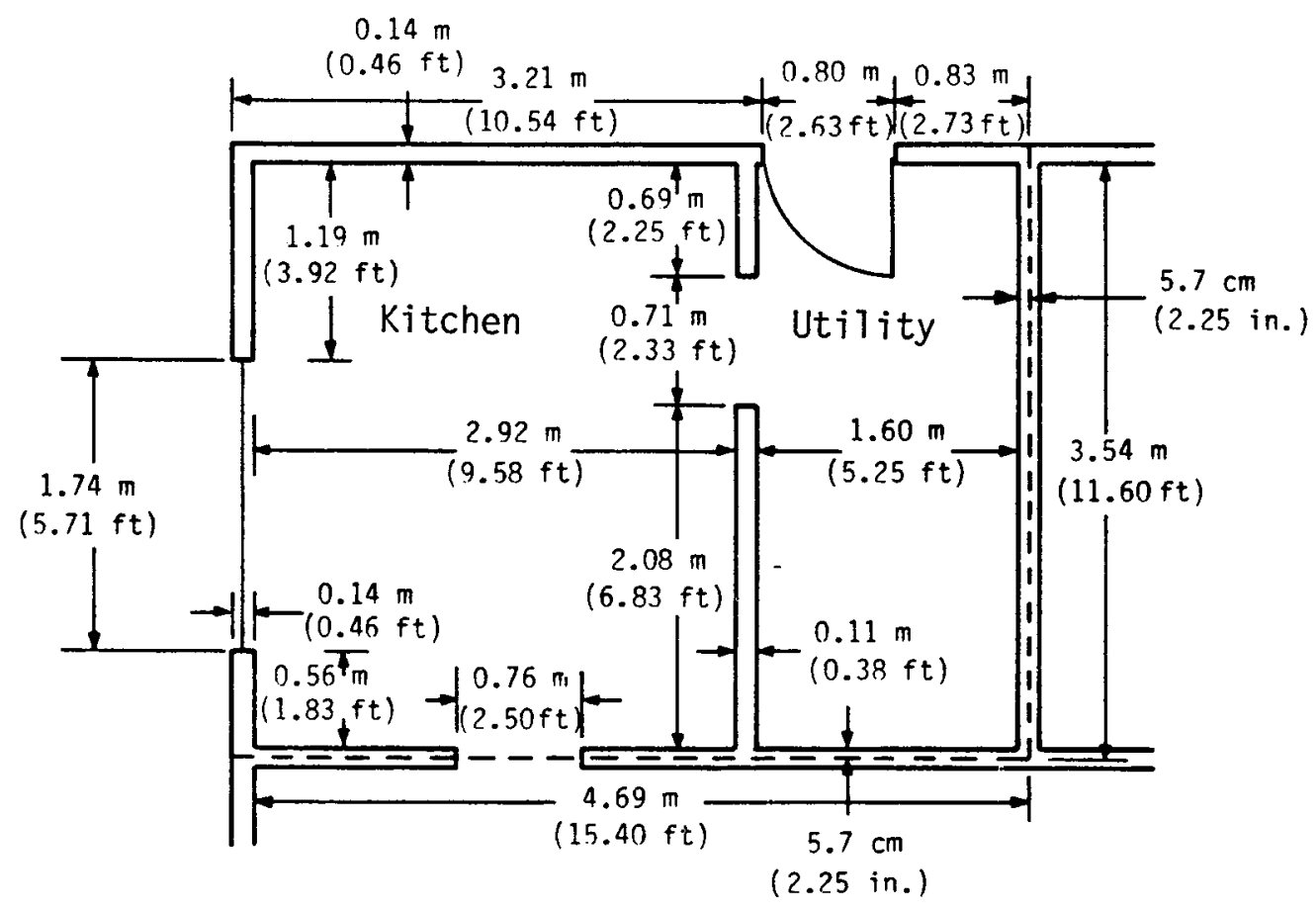

Fig. 8. Zone 1 fioor-plan dimensions.

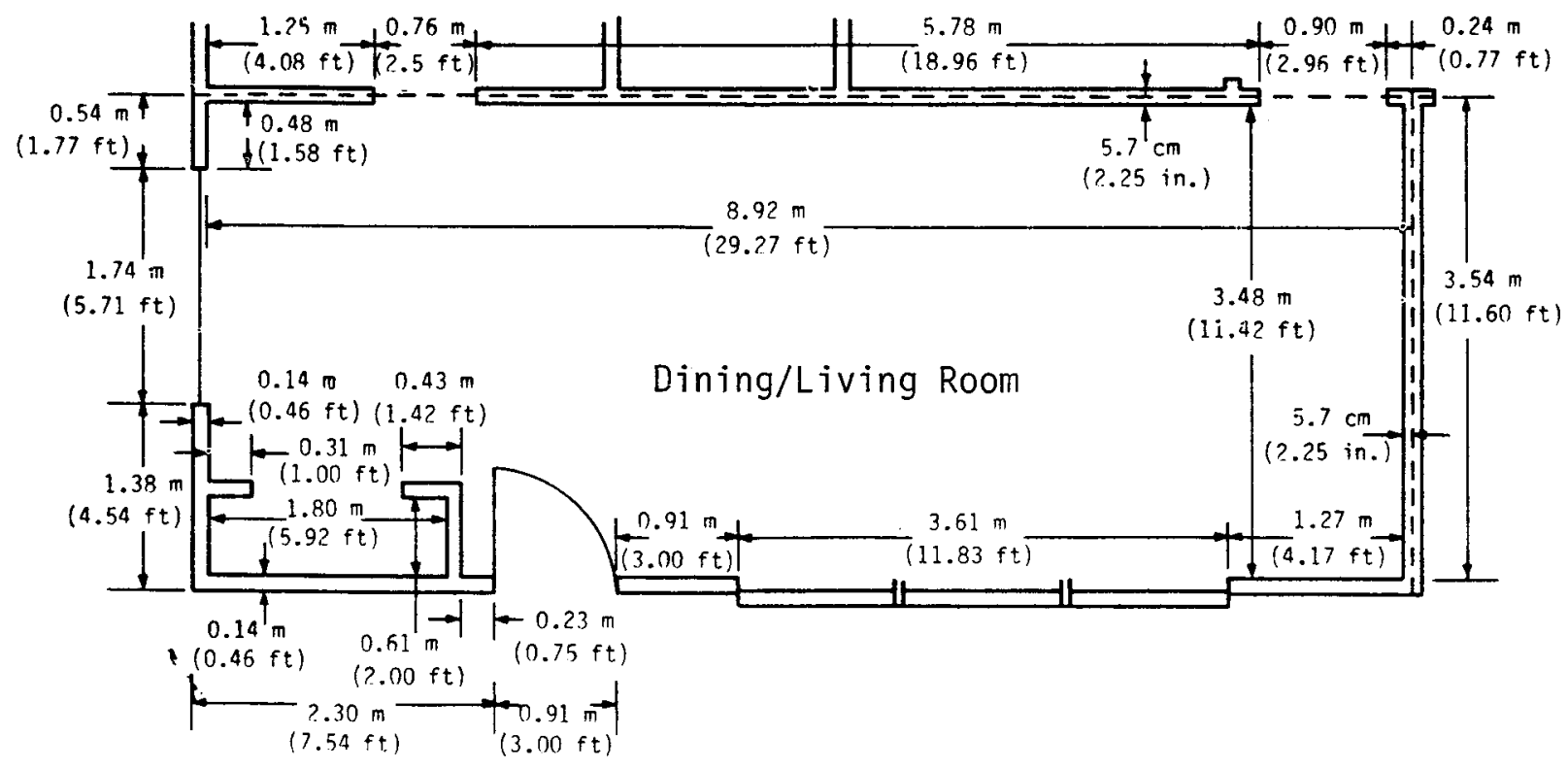

Fig. 9. Zone 2 rloor-plan dimensions. 


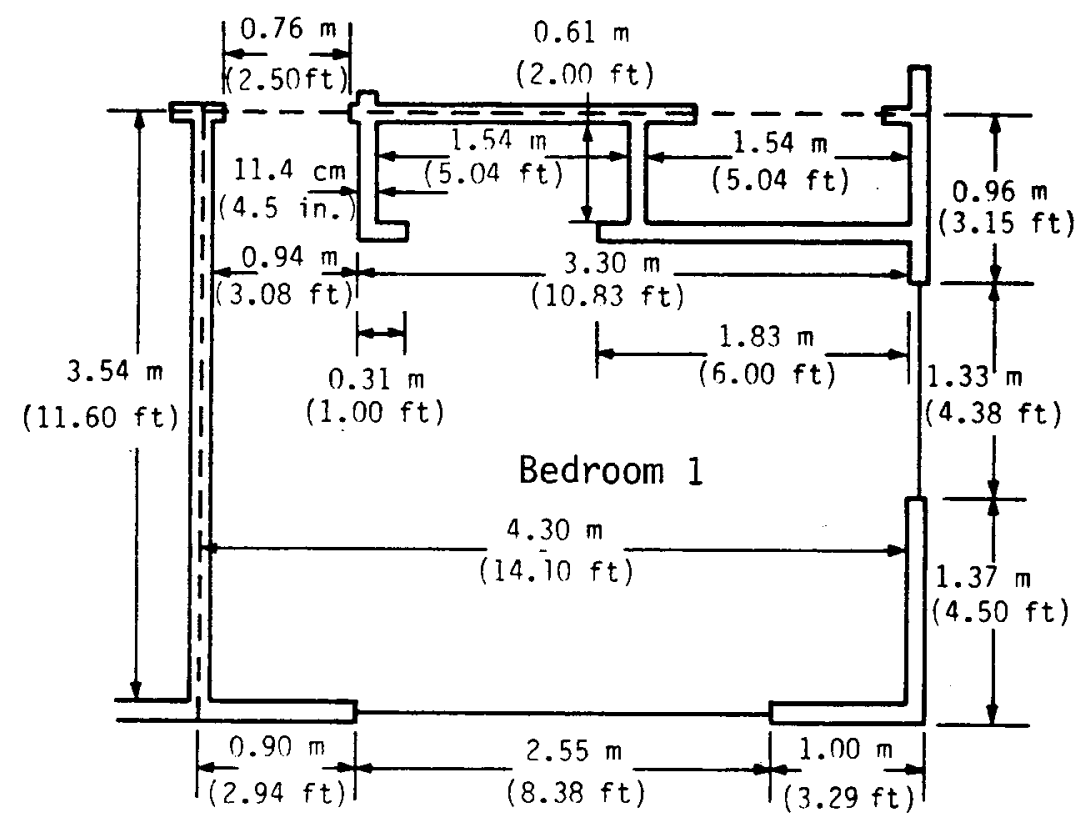

Fig. 10. Zone 3 floor-plan dimensions.

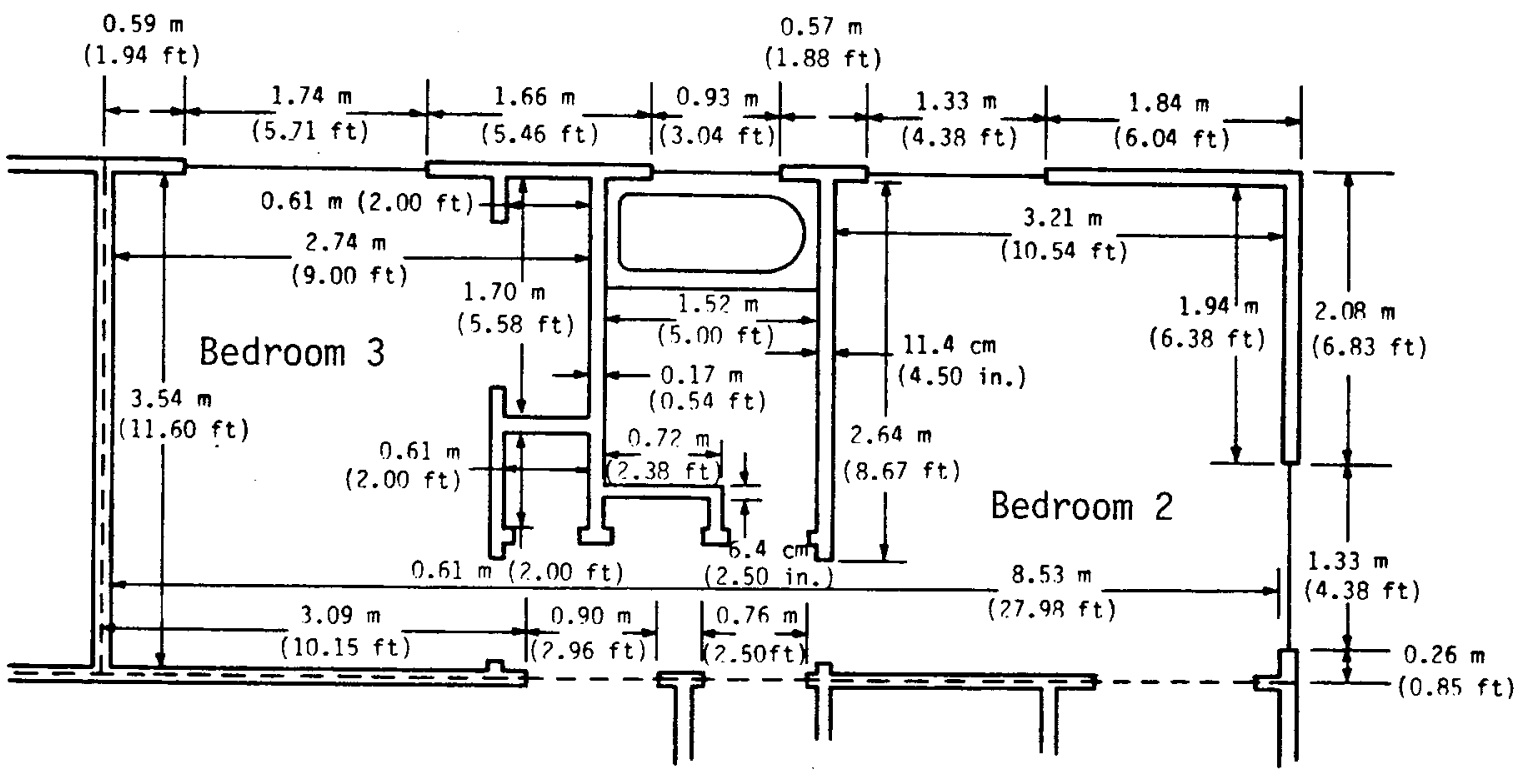

Fig. 11. Zone 4 floor-plan dimensions. 
TABLE II

ZONAL AREA AND VOLUME SUMMARY

\begin{tabular}{clcc} 
Zone & $\begin{array}{c}\text { Floor } \\
\text { Area } \\
{\left[\mathrm{m}^{2}\left(\mathrm{ft}^{2}\right)\right]}\end{array}$ & $\begin{array}{c}\text { Vol ume } \\
{\left[\mathrm{m}^{3}\left(\mathrm{ft}^{3}\right)\right]}\end{array}$ \\
\hline 1 & Kitchen/utility & $16.6(179)$ & $40.5(1429)$ \\
2 & Dining/1iving room & $31.6(340)$ & $76.9(2717)$ \\
3 & Bedroom 1 & $15.2(163)$ & $37.0(1308)$ \\
4 & Bedrooms 2 and 3, bath & $30.2(325)$ & $73.5(2596)$ \\
\hline Building & $93.6(1007)$ & $228.0(8050)$
\end{tabular}

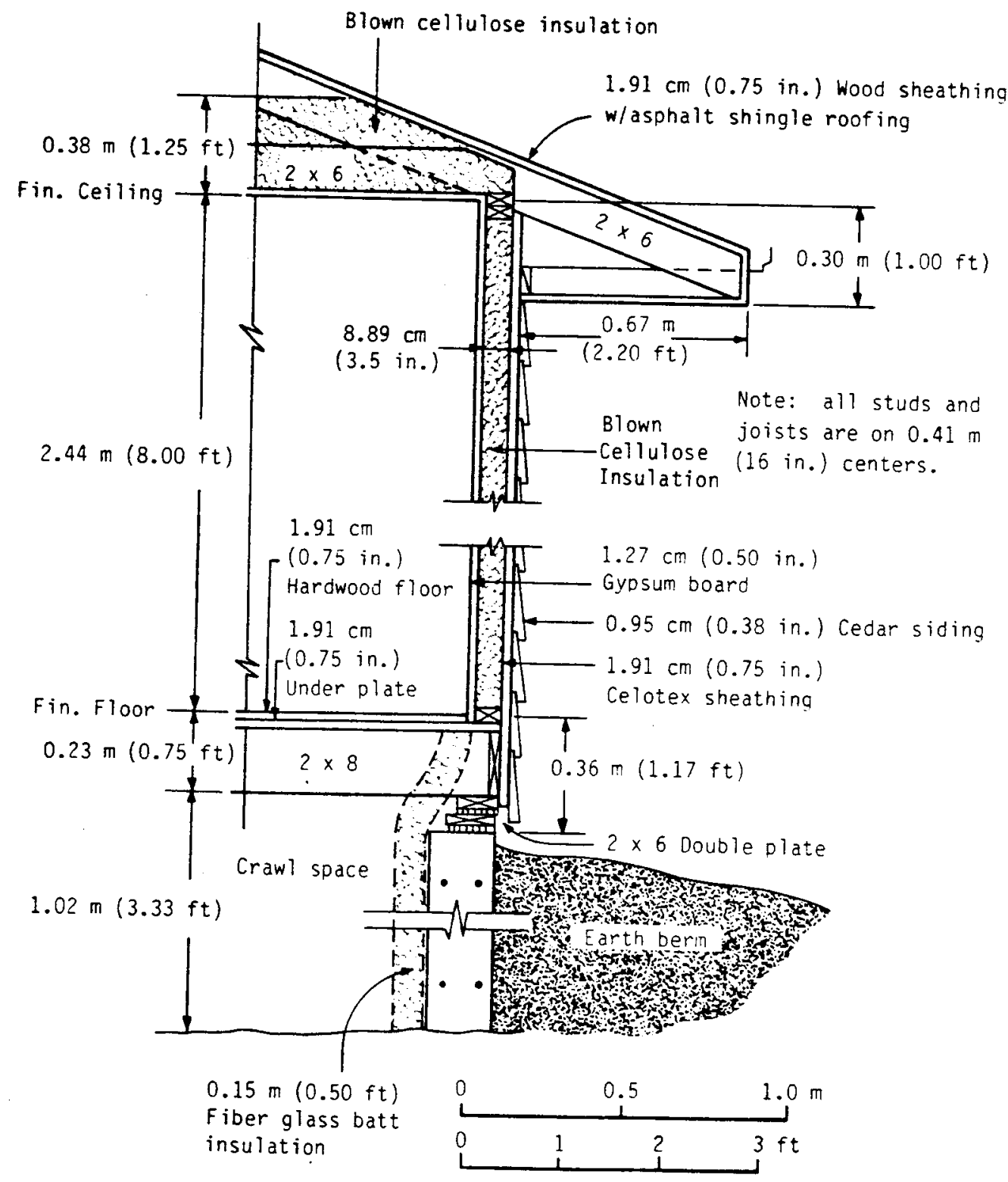

Fig. 12. Typical (north or south) wall section. 


\section{TABLE III}

\section{ENVELOPE CONSTRUCTION DESCRIPTIONS}

Interior Walls

$1.27 \mathrm{~cm}(0.50 \mathrm{in.})$ gypsum board

$6.35 \mathrm{~cm}(2.50$ in.) air space

$1.27 \mathrm{~cm}(0.50 \mathrm{in.})$ gypsum board

Exterior Wall Type 1 (North, East, West, and $53.3 \%$ of South Wall Siding) (See Fig. 6)

$1.27 \mathrm{~cm}(0.50$ in.) gypsum board

$8.89 \mathrm{~cm}$ (3.50 in.) blown cellulose insulation

$1.91 \mathrm{~cm}(0.75 \mathrm{in.})$ Celotex

$0.95 \mathrm{~cm}(0.375 \mathrm{in}$.) cedar siding

Exterior Wall Type 2 (46.7\% of South Wall Siding)

$1.27 \mathrm{~cm}(0.50$ in.) gypsum board

$8.89 \mathrm{~cm}$ (3.50 in.) bl own cellulose insulation

$1.91 \mathrm{~cm}(0.75 \mathrm{in.})$ Celotex

$0.79 \mathrm{~cm}(0.31 \mathrm{in}$.$) plywood$

Tile Flooring (Kitchen, Bathroom)

$0.32 \mathrm{~cm}(0.125$ in.) linoleum

$0.16 \mathrm{~cm}(0.063 \mathrm{in.})$ tar paper sheet

$1.91 \mathrm{~cm}$ (0.75 in.) hardwood (oak)

2 sheets paper

$1.91 \mathrm{~cm}(0.75 \mathrm{in.})$ subfioor

Wooden Flooring (Bedrooms 2 and 3)

$1.91 \mathrm{~cm}(0.75 \mathrm{in.})$ hardwood (oak)

2 sheets paper

$1.91 \mathrm{~cm}(0.75$ in.) subfioor

Brick Flooring (Living Room, Dining Room, and Bedroom 1)

$5.72 \mathrm{~cm}(2.25 \mathrm{in}$.) common red brick

Plastic sheeting

$1.91 \mathrm{~cm}(0.75 \mathrm{in.})$ hardwood (oak)

2 sheets paper

$1.91 \mathrm{~cm}(0.75$ in.) subfloor, softwood (pine)

Ceiling

$\overline{1.27 \mathrm{~cm}}(0.50 \mathrm{in.})$ gypsum board

$0.38 \mathrm{~m}$ (15.00 in.) blown cellulose insulation

Gable Walls (East, West Attic End Walls)

$1.97 \mathrm{~cm}(0.75 \mathrm{in}$. ) Celotex

$0.79 \mathrm{~cm}(0.375 \mathrm{in}$.) cedar siding

Roof

$\overline{1.97} \mathrm{~cm}(0.75 \mathrm{in.})$ subfloor underplate, softwood

$0.16 \mathrm{~cm}(0.063 \mathrm{in}$.$) tar paper sheet$

$0.48 \mathrm{~cm}(0.188 \mathrm{in.})$ asphalt shingle

$0.48 \mathrm{~cm}(0.188 \mathrm{in.})$ asphalt shingle

Al1 joists and framing are $0.41 \mathrm{~m}$ (16 in.) on center. All walls have a single plate $(2 \times 4)$ at bottom and a double plate $(2 \times 4)$ at top. 


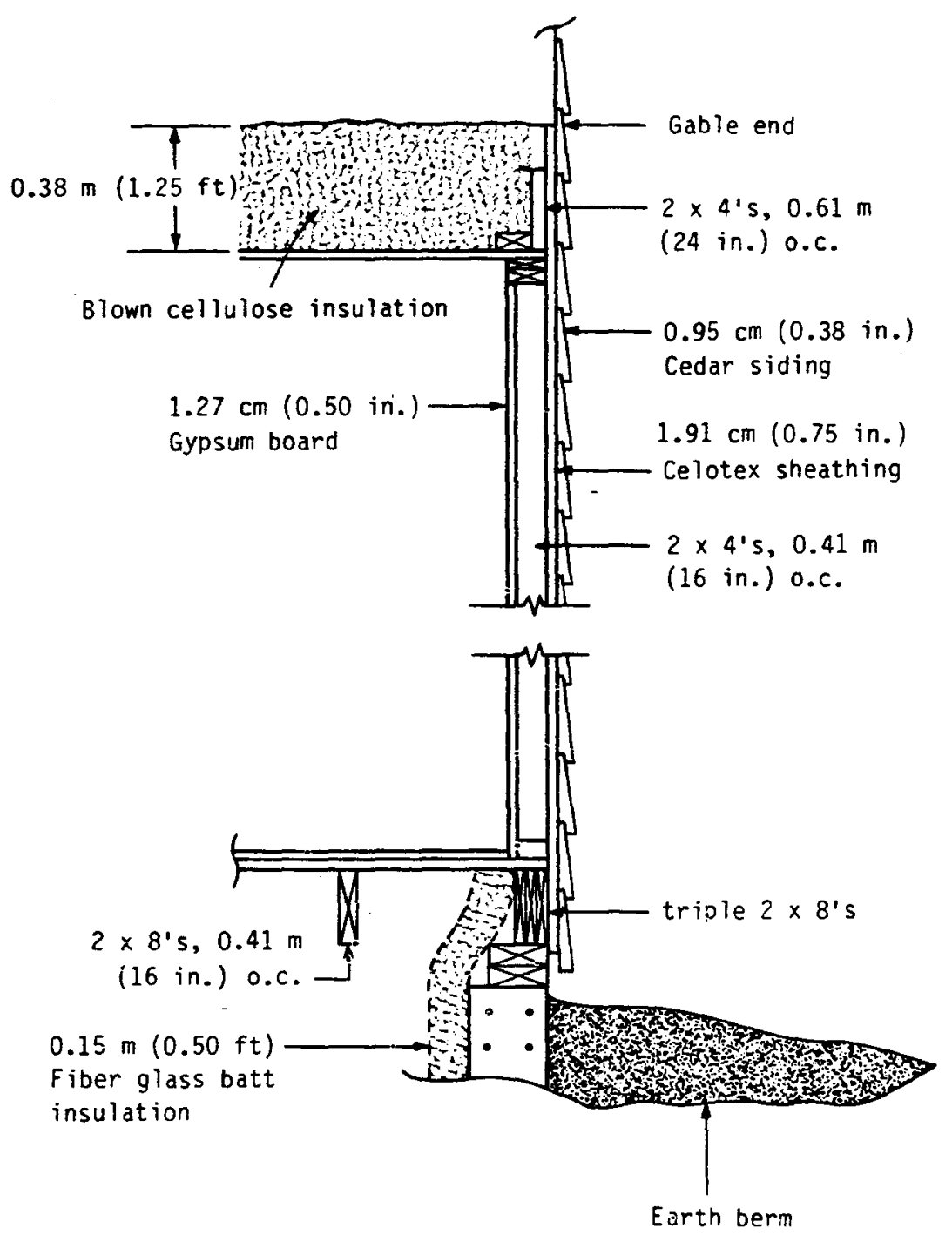

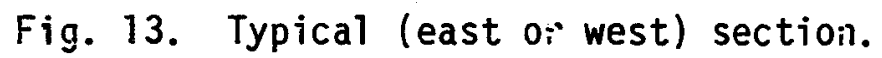

$\mathrm{ft}^{2}$ ) of open air flow, were installed on July 20, 198?, in the attic, with two louvers at the apex of both the east and west gables (see Figs. 6 and 7). The louvers were required for a whole-house fan that was installed in mid-july 1982. Outside walls are painted a pastel green, and inside walls and ceilings are all flat white.

\section{A. Windows}

The locations of the windows are shown in the building elevations (Figs. 4-7). The top of all window frames is iocated $5.72 \mathrm{~cm}(2.25 \mathrm{in}$.) below the bottom of the roof overiang.

The windows, except on the south side, of the living room were originălly of the single-glazed, steel casement type. All windows (except that in 
the north door) have been retrofitted with an interior, aluminum-frame storm sash that holds the inner glazing. Except for the living room south window, all windows have the outer glazing held in a steel frame; the living room south window has a wooden frame holding the outer glazing (see Fig. 14). The typical sash configuration for all but the living room south window is shown in Fig. 15; the number of lites differs from window to window, but the relative dimensions are identical. The exterior of the window frames is painted dark green (solar absorptance $\simeq 0.89$ ).

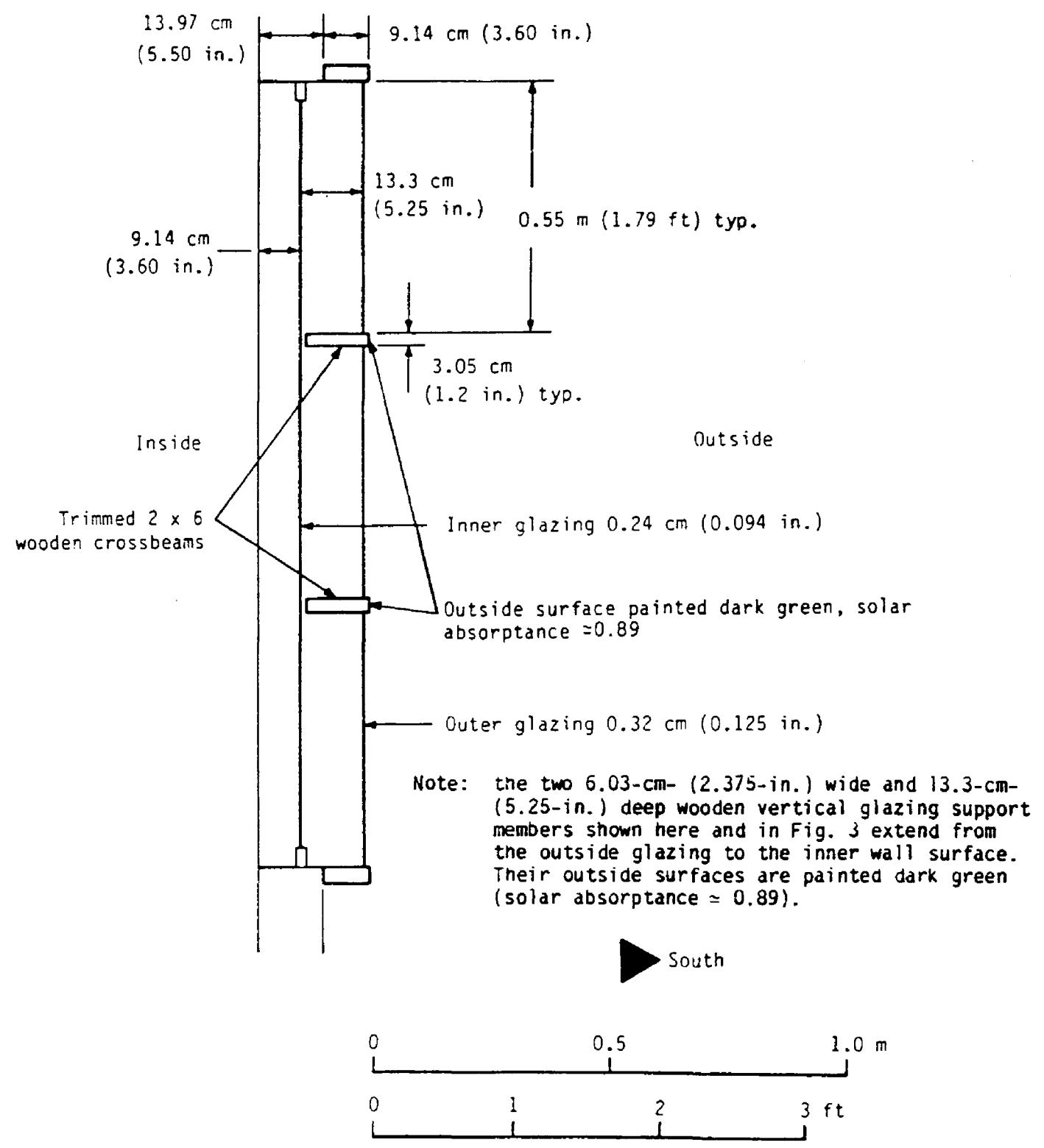

Fig. 14. Uining/living room window section. 


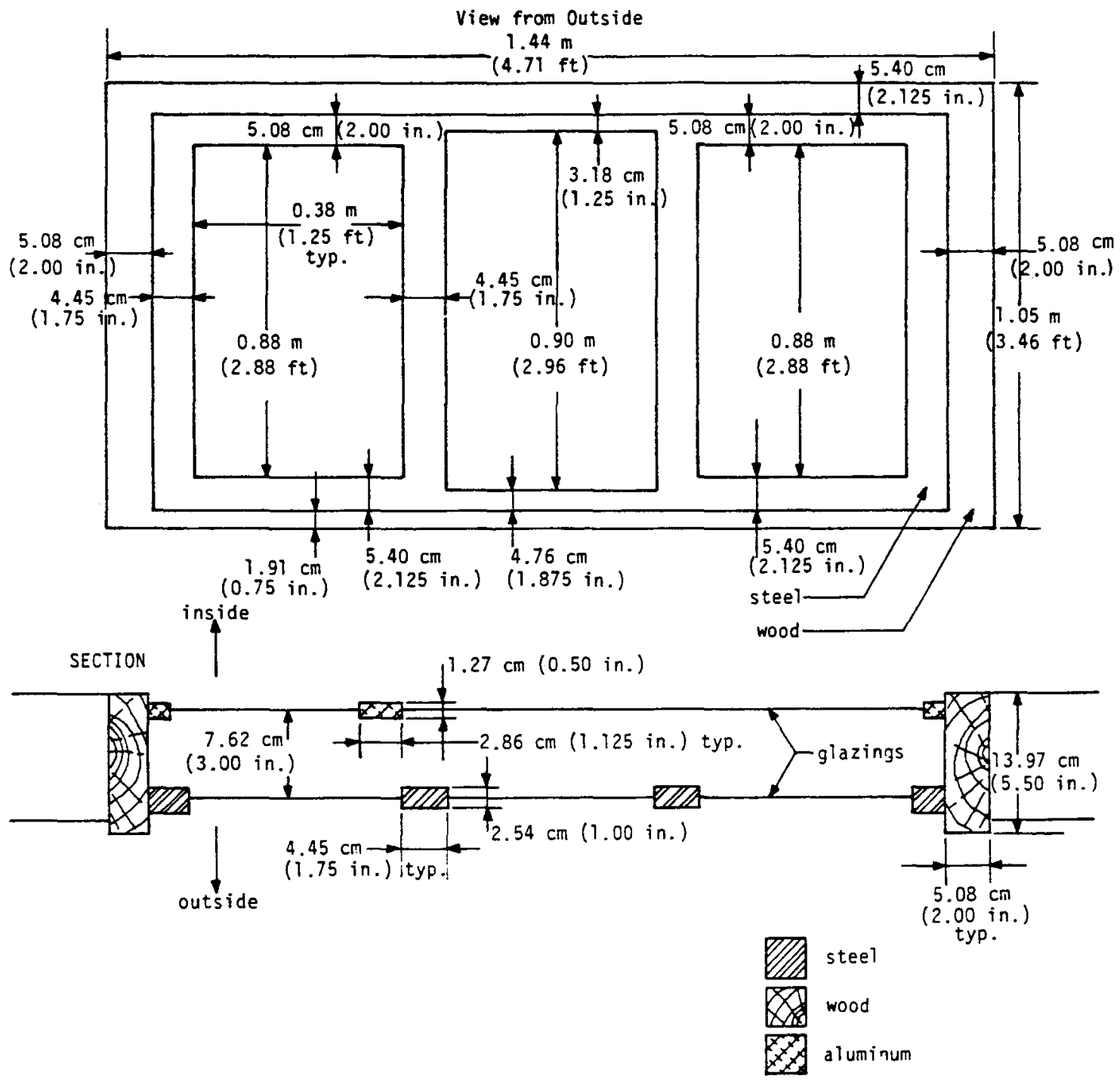

Fig. 15. Typical window section (except dining/living room window).

On all windows the outer pane is $0.32-\mathrm{cm}(0.125-\mathrm{in}$.$) -thick glass and$ the inner pane is $0.24-\mathrm{cm}(0.094-i n$. $)$-thick glass. All windows except the living room south window have a $7.62-\mathrm{cm}(3.00-i n$.) air gap between panes, the living room south window has a $13.3-\mathrm{cm}(5.25-\mathrm{in}$.) air gap, a vertical section of this window is shown in Fig. 14. Glaziny constitutes $11.9 \%$ of the northwall exterior surface, $21.3 \%$ of the south-wal1 exterior surface, $7.7 \%$ of the east, and $13.8 \%$ of the west. Table IV shows the percentage of glazing to the gross area of the frame for each window. All window frames have been carefully cauliked to reduce air leakage. 
TABLE IV

WINDOW DESCRIPTIONS

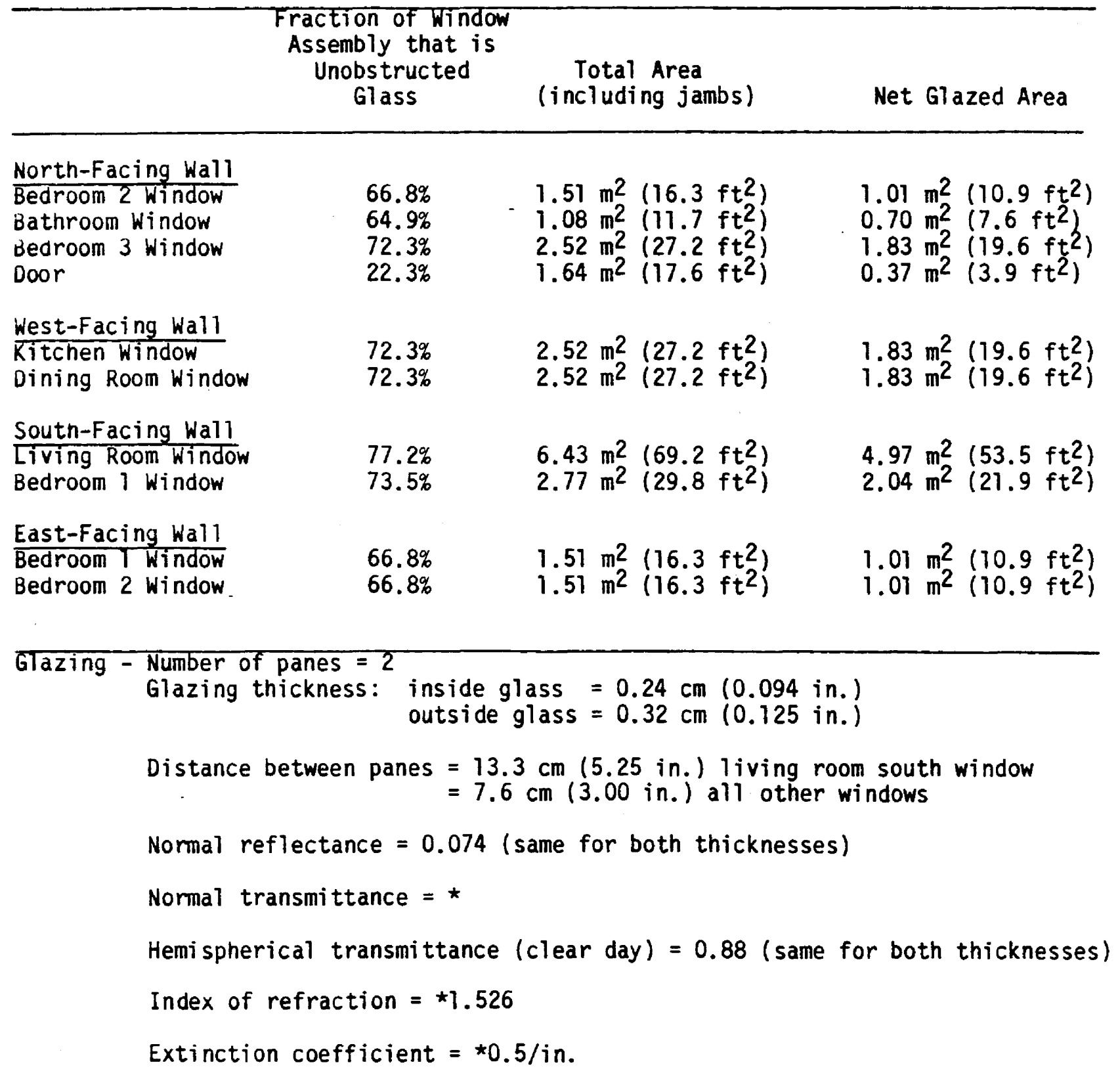

*Measured values not available at present; 1 isted value is taken from Ref. 2 , if available. 
Note that the south window in the 1 iving room will experience significant blockage of solar radiation because of the glazing support structure (see Fig. 14). The horizontal bottom ledge and the four vertical support members (one on each side and two in the middle) each extend back $22.7 \mathrm{~cm}$ (8.94 in.) from the outer glazing. Also, the two horizontal members located between the inner and outer glazings will intercept considerable beam radiation during solar equinox periods. The radiation transmitted to the living room should be adjusted to account for this situation.

B. Doors

The two exterior doors are both wooden hollow-core flush doors with al uminum and glass storm doors; the south door is 4.45-cm (1.75 in.) thick and the north door is $3.49-\mathrm{cm}(7.375-\mathrm{in}$.) thick. An $8.89-\mathrm{cm}(3.50-\mathrm{in}$.) air space separates the exterior doors from the storm doors. The nortin door has a single-glazed panel, as shown in Fig. 4, that covers $22 \%$ of the total door area.

\section{Description of Passive Solar and Conservation Features}

The test house is a direct-gain system, with $7.0 \mathrm{~m}^{2}\left(75 \mathrm{ft}^{2}\right)$ of south-facing glazing, and $5.7 \mathrm{~m}^{2}\left(61 \mathrm{ft}^{2}\right)$ of east- and west-facing glazing. This corresponds to a south glazing-area-to-floor-area ratio of 7.5\%. A small amount of diffuse solar radiation enters the house through north-facing windows. The sloping roof overhang projects out $0.67 \mathrm{~m}(2.20 \mathrm{ft})$ from the south wall just above the vindows and provides shading during the summer months. No movable insulation or drapes are used on any of the windows.

Thermal storage is provided by $5.72-\mathrm{cm}(2.25-i n$.$) thick, common red$ brick covering virtually the entire floor in the dining room/living room and in the south bedroom, and by $1.27-\mathrm{cm}(0.50-\mathrm{in}$.$) gypsum board on 211$ walls and ceilings. The solar absorptance of the brick floor is 0.82 and that of the gypsum board is 0.36 . The kitchen and utility rooms (Zone 1 ) contain significant thermal capacitance in excess of that contained in the building structure. This excess capacicance is contained primarity in the form of metal cabinets and monitoring equipment. Table $V$ lists the major categories of mass, their weight, and estimated values for specific heat. This mass, which approximately doubles the effective thermal storage mass of the interior walls and floors in Zone 1 , is well coupled to the room air. Additional thermal and physical properties of these elements are given in Appendix A. 
TABLE $V$

ADDITIONAL THERMAL MASS IN KITCHEN AND UTILITY ROOM

Room and Description of Mass

1. Utility room monitoring equipment: metal

2. Sink in utility room: highdensity concrete, some metal

3. Kitchen cabinets: mostiy metal and formica

4. Other kitchen equipment: mostly metal
Weight

$302 \mathrm{~kg}(666 \mathrm{lb}) \quad 502 \mathrm{~J} / \mathrm{kg}^{\circ} \mathrm{C}\left(0.12 \mathrm{Btu} / 1 \mathrm{~b}^{\circ} \mathrm{F}\right)^{\mathrm{a}}$

$68 \mathrm{~kg}(150 \mathrm{lb})$

$879 \mathrm{~J} / \mathrm{kg}^{\circ} \mathrm{C}\left(0.21 \mathrm{Btu} / 1 \mathrm{~b}^{\circ} \mathrm{F}\right)^{\mathrm{b}}$

$250 \mathrm{~kg}(552 \mathrm{lb}) \quad 586 \mathrm{~J} / \mathrm{kg}^{\circ} \mathrm{C}\left(0.14 \mathrm{Btu} / 7 \mathrm{~b}^{\circ} \mathrm{F}\right)^{\mathrm{C}}$

$52 \mathrm{~kg}(114 \mathrm{lb}) \quad 502 \mathrm{~J} / \mathrm{kg}^{\circ} \mathrm{C}\left(0.12 \mathrm{Btu} / 1 \mathrm{~b}^{\circ} \mathrm{F}\right)^{\mathrm{a}}$

aAssuming $90 \%$ steel and iron, $10 \%$ al uminum.

bconcrete.

CAssuming $80 \%$ steel and iron, $20 \%$ formica.

Cellulose insulation was blown into the $8.89-\mathrm{cm}(3.5-i n$.$) exterior wall$ cavities, and 0.38-m (15.0-in.) was blown onto the attic floor. Extensive caulking was done on all windows and door frames, and on any other cracks and possible air leaks. R-19 fiber glass batts were installed on the inside of the foundation wall and outer joist box, as shown in Fig. 12. This insulation extends up to the bottom of the floor and down to the bottom of the foundation stem wall.

D. Heating, Ventilating, and Air Conditioning (HVAC) System and Plant

\section{Description}

Auxiliary heating is provided by Dayton Model 441-E 3.5-kW 111940 $\mathrm{Btu} / \mathrm{h}), 208-\mathrm{V}$ electric-resistance heaters with fans, there are two heaters in Zones 2 and 4 , and one heater in each of the other two zones. After March 1982, only one of the two heaters has been used in Zones 2 and 4 . The heater therinostats are located inside the shield of the nearest zonal temperaturesensing unit, and therefore should see the same temperature as the zone air. 
These Dayton Model 2E173 thermostats had a deadband of about $1^{\circ} \mathrm{C}\left(1.8^{\circ} \mathrm{F}\right)$, and controlled the temperature of each zone to about $\pm 0.6^{\circ} \mathrm{C}\left( \pm 1^{\circ} \mathrm{F}\right)$. (Pneumatic thermostats provided with the units proved unreliable.) To provide cooling, a Sears Model 42K64077N248.7W [0.25 kW (1/3 hp)], 0.762-m (30-in.)-diameter whole-house fan [approximately $10,000 \mathrm{~m}^{3} / \mathrm{h}(1350 \mathrm{cfm})$ ] was installed during June 1982, and therefore was not present during the previous heating season. Details of control strategies used are given in individual experiment descriptions.

IV. DATA ACQUISITION AND TEST CONDITIONS

\section{A. Description of Sensors}

With sensor symbols defined in Fig. $B-1$, the building instrumentation plans are shown in Figs. B-2 through B-6 of Appendix B. A list of data recorded hourly (channel directory) is given in Appendix $C$. Unless noted otherwise, vertical placement is at the midpoint of the monitored space or surface. The instrumentation was developed to satisfy the following measurement requi rements:

1. measure air temperature of each zone with a triply shielded thermocouple placed near the zone center point (for the living room, temperature is monitored at midpoints of two equal volumes);

2. define heater, fan, and other electrical power into each zone with Hall-effect wattmeters that account for all voltage, current, and phase conditions, measuring total power with a zone-by-zone breakdown;

3. install rakes at two or more locations for each principal wall type, consisting of a heat-flux meter, a surface thermocouple, and differential thermocouples across all homogeneous wall layers (see Ref. 3);

4. monitor inside-outside surface temperatures of each wall type at each orientation, from which flux can be inferred, using correlations derived from the rakes with flux meters (see Ref. 3);

5. measure infiltration continuously zone-by-zone, using tracer-gas decay (see Ref. 4);

6. measure transmitted global vertical solar radiation through each window orientation; 
7. instrument all living room walls as described in either 3 or 4 above, to allow a complete zonal energy balance in the living room, including the wall conduction losses, infiltration (as in 5 above), and transmitted solar radiation (as in 6 above);

8. monitor foundation-wall-surface heat fluxes at the midpoint of each principal orientation;

9. monitor ground temperatures down to $2 \mathrm{~m}(6.6 \mathrm{ft})$ depth and surface fluxes and 6 evenly spaced locations, and determine north/south variation of ground surface flux across the crawl space;

10. monitor globe temperature in several zones at $0.6 \mathrm{~m}(5.35 \mathrm{ft})$ height.

The site weather data are taken at 4-second intervals and recorded in one-minute averages (see Ref. 3 ). Total horizontal radiation is measured at the site Lapproximately $90 \mathrm{~m}(300 \mathrm{ft})$ east of the test house」 with an Eppley pyranometer, Model PSP ( $+3 \%$ accuracy), south-facing vertical radiation outside the south aperture is measured with an Eppley pyranometer, Model PSP $(+8 \%$ accuracy). Another Eppley Model PSP pyranometer ( $+5 \%$ accuracy), mounted in an inverted position $1 \mathrm{~m}(3.28 \mathrm{ft})$ above the ground at the location of the total horizontal radiation pyranometer, is used to measure ground reflected radiation. Direct-normal (beam) radiation is measured using an Eppley normal incidence pyrheliometer, Model NIP ( $+1 \%$ accuracy). No diffuse radiation is measured, it is deduced from the total horizontal and direct-normal measurements. Kipp and Zonen Mode1 CM6 pyranometers ( $+8 \%$ accuracy when tilted, $\pm 3 \%$ accuracy horizontal) are used to measure transmitted solar radiation inside the apertures.

The site weather station takes wind speed and direction measurements at 2 and $10 \mathrm{~m}(6.6$ and $32.8 \mathrm{ft})$ using a Teledyne Geotech instrument $( \pm 3 \%$ accuracy). Ambient temperatures $\left( \pm 7^{\circ} \mathrm{F}\right.$ accuracy) are measured using a shielded and shaded thermocouple (type $\mathrm{J}$ ), whereas the relative humidity is measured using a Texas Instruments Model TH-2013-2 sensor (accuracy is $\pm 5 \%$ for $\mathrm{RH}=5-15 \%$ and $+2 \%$ for $\mathrm{RH}=20-90 \%$ ). Barometric pressure is measured with a Setra Systems, Inc. Model 270 pressure transducer. Finally, night-sky infrared radiation is measured with a Teledyne Geotech Model 188 sensor ( $+5 \%$ accuracy).

A11 temperatures $\left(+0.8^{\circ} \mathrm{F}\right.$ accuracy in situ) and differentid temperatures $(+0.6 \%$ accuracy in situ) in and beneath the house are measured with type $\mathrm{J}$ tinermocouples. Heat fluxes are measured using Valley Laboratories Research 
and Development Company transducers; Mode1 T335 (approximately $\pm 10 \%$ accuracy in situ) is used for all ground locations and Model T225 (approximately $\pm 10 \%$ accuracy in situl is used for all other locations. Finally, electrical power is measured using Ohio Semetronics Model PC5 wattmeters ( $\pm 0.5 \%$ accuracy). A complete listing of monitored channels is given in Appendix $C$.

\section{B. Description of Data-Acquisition System}

Pyranometers, wattmeters, and some differential thermocouples are sampled every 15 seconds; the remaining sensors are sampled every five minutes. These are converted to hourly averages and recorded at the site. Data reduction and editing are done on the SERI mainframe computer.

A Fluke Model 2240B data-acquisition system, with Model 2201 and 2202 remote scanners and a high-performance digital voltmeter $( \pm 0.02 \%$ of reading accuracy), is used for collecting 190 channels of building data. The remaining 37 channels of building data are collected with a Kinetic Systems Model $3553 \mathrm{C}$ $A / D$ data-acquisition system that includes a digital voltmeter with $\pm 0.01 \%$ accuracy. The digital vol tmeter used for the weather data has $\pm 0.00 \%$ accuracy.

\section{One-Time and Special Measurements}

A coheating test to measure the overall conduction loss coefficient for the building was conducted for three nights during May 1982 at a constant inside ambient temperature. During the day the windows were covered to prevent solar gain. The results are not fully analyzed, but preliminary analysis indicates a load coefficient of about $106 \mathrm{~W} /{ }^{\circ} \mathrm{C}\left(200 \mathrm{Btu} / \mathrm{h}-{ }^{\circ} \mathrm{F}\right)$.

An infrared thermographic scan was taken to determine major energyleakage paths, any obvious leakage paths were sealed to prevent further major energy losses. A blower door was also used to find leaks, which were then caulked. Major leak areas were located at plumbing penetrations, water heater vents, and hallway baseboards. Effective leakage crack area was determined before and after each of a series of conservation measures was taken, results are shown in Fig. 16. The final blower door test results indicate an airchange rate of $0.73 \mathrm{ac} / \mathrm{h}$ at $4 \mathrm{~Pa}$ pressurization and $4.41 \mathrm{ac} / \mathrm{h}$ at $50 \mathrm{~Pa}$.

D. Hourly Data Tape

Houriy measured data are available on an unlabeled 9-Track, 1600 BPI magnetic tape, written in ASCII code, the blocking and format are indicated on 


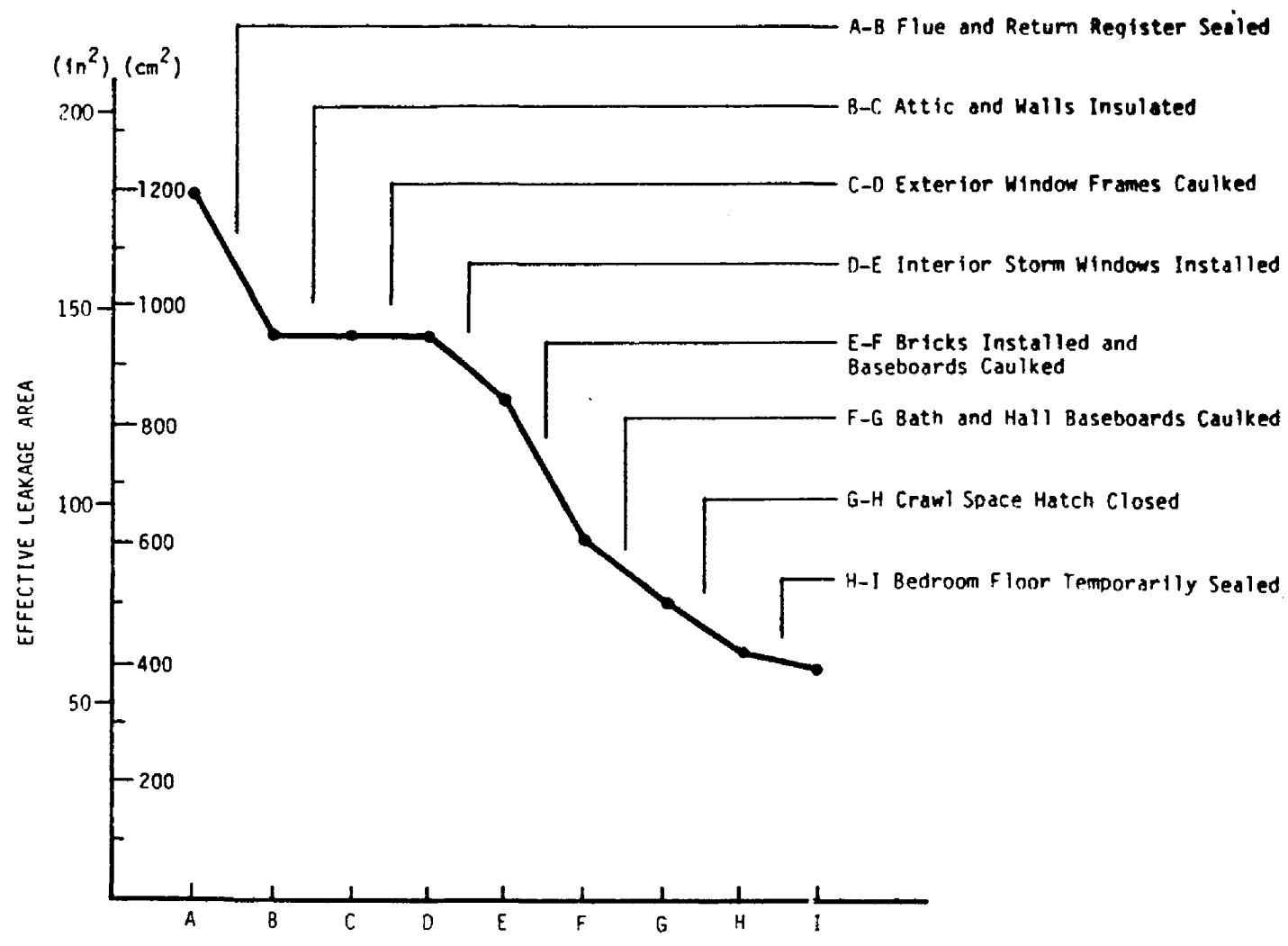

Fig. 16. Reduction in infiltration resulting from envelope integrity improvements.

the header file and in the tape documentation. The channel directory for this tape is presented in Appendix $C$.

\section{E. Test Conditions}

Detailed test conditions are described in documentation accompanying the hourly data tapes. In general, while data were taken the house was closed and unoccupied, no lights were on, but the destratifiers were in continuous operation. Destratifiers (Stratojet 25-W) were used in all zones except Zone 4 where a 225-W (184-W measured) Dayton 4C445 blower and air duct assembly was used. 


\section{SUMMARY}

This site handbook gives a detailed description of the construction, instrumentation, and test configuration of the SERI Validation Test House in Golden, Colorado. This facility is being used to collect performance data for analysis/design tool validation as part of the DOE Passive Solar Class A Performance Evaluation Program.

\section{REFERENCES}

1. "Regional Guidelines for Building Passive Energy Conserving Homes," prepared by the AIA/RC for the U.S. Department of Housing and Urban Devel opment, HUD-PDR-355 (November 1978), p. 65.

2. ASHRAE Handbook of Fundamentals, 1981 (American Society of Heating, Refrigerating, and Air-Conditioning Engineers, Atlanta, Georgia, 1981).

3. R. Judkoff, D. Wortman, J. Burch, and B. O'Doherty, Validation of Building Energy Simulations, SERI report to be published.

4. D. N. Wortman, J. Burch, and R. Judkoff, "A Mul tizone Infiltration Monitoring System," Proc. of the 7 th National Passive Solar Conference, August 30-September 1, 1982, Knoxville, Tennessee (American Solar Energy Society, Newark, Delaware, 1982), pp. 767-771. 
APPENDIX A

MATERIAL PROPERTIES 
TABLE A-I

MATERIAL PROPERTIES。

(English Units)

\begin{tabular}{|c|c|c|c|c|c|}
\hline Materials & $a_{s}$ & $\varepsilon$ & $\left(B t u / h-f t-{ }^{o} F\right)$ & $\left(1 \mathrm{~b} / \mathrm{ft}^{3}\right)$ & $\frac{C_{p}}{\left(B+u / l b-o_{F}\right)}$ \\
\hline Gypsum board $-127 \mathrm{~cm}(0.50 \mathrm{ln})$. & $0.36^{b}$ & 0.90 & 0.093 & 50. & 0.26 \\
\hline Cedar siding $-0.95 \mathrm{~cm}(0.375 \mathrm{in.})$ & $0.52^{b}$ & $d$ & 0.067 & 32. & 0.33 \\
\hline $\begin{array}{l}\text { Cellulose insulation, walls }-8.89 \mathrm{~cm} \\
(3.50 \mathrm{in.})\end{array}$ & - & - & $0.0167 c$ & $2.7 c$ & $0.33 c$ \\
\hline $\begin{array}{l}\text { Cellulose insulation, cefling } \\
0.38 \mathrm{~m}(15.00 \mathrm{in.})\end{array}$ & - & - & $0.0167 c$ & 2.76 & $0.33 c$ \\
\hline $\begin{array}{l}\text { Studs }(2 \times 4 \mathrm{~s}), \text { walls }-8.89 \mathrm{~cm} \\
(3.50 \mathrm{in.})\end{array}$ & & & 0.067 & 32. & 0.33 \\
\hline Soil. under crawlspace & d & d & 0.5 & 125. & 0.20 \\
\hline Soil, berm & $d$ & $d$ & 0.75 & 131. & 0.23 \\
\hline Plywood $-0.79 \mathrm{~cm}(0.313 \mathrm{in.})$ & $0.52^{b}$ & 0 & .0 .067 & 34. & 0.29 \\
\hline Asphalt shingles $-0.48 \mathrm{~cm}(0.188 \mathrm{in.})$ & $0.90^{b}$ & 0 & a & 70 & 0.30 \\
\hline Hardwood (oak) $-1.91 \mathrm{~cm}(0.75$ in.) & $0.49 \mathrm{D}$ & 0.90 & 0.102 & 47. & 0.57 \\
\hline Subfloor $-1.91 \mathrm{~cm}(0.75 \mathrm{in.})$ & - & $d$ & 0.067 & 32. & 0.33 \\
\hline Common red brick $-5.72 \mathrm{~cm}$ (2.25 in.) & $0.82^{b}$ & $d$ & 0.20 & 123 & 0.20 \\
\hline Linoleum tile $-0.32 \mathrm{~cm}(0.125 \mathrm{in.})$ & 0.710 & $d$ & d & d & d \\
\hline Celotex (sheathing) & - & - & 0.0316 & 18. & 0.31 \\
\hline Concrete & - & 0 & 0.54 & 144. & 0.156 \\
\hline Fiber glass insulation & - & - & 0.024 & 1.3 & 0.17 \\
\hline Tar paper & - & - & $\sigma$ & d & 0 \\
\hline
\end{tabular}

Ground albedo: Unimproved fields $=0.23 b$

Gravel areas $=d$

\footnotetext{
a Listed value is taken from Ref. 2, except as otherwise noted.

bineasured property.

cStuds are not included in these properties: themal conductivity is a measured value.

dunavallable.
} 
IABLE A-II

MATERIAL PROPERTIES

(SI Units)

\begin{tabular}{|c|c|c|c|c|c|}
\hline Materials & $\alpha_{S}$ & $\varepsilon$ & $w / m-{ }^{\circ} \mathrm{C}$ & $\mathrm{kg} / \mathrm{m}^{3}$ & $\mathrm{~J} / \mathrm{kg}-{ }^{\circ} \mathrm{C}$ \\
\hline Gypsum board - $127 \mathrm{~cm}(0.50 \mathrm{in.})$ & $0.36^{b}$ & $0.9 C$ & 0.161 & 801 . & 1089 \\
\hline Cedar siding $-0.95 \mathrm{~cm}(0.375 \mathrm{in.})$ & $0.52 \mathrm{~b}$ & $d$ & 0.115 & 513. & 1382. \\
\hline $\begin{array}{l}\text { Cellulose insulation, walls }-8.89 \mathrm{~cm} \\
(3.50 \mathrm{in.})\end{array}$ & - & - & $0.029 \mathrm{C}$ & 43. & 1382. \\
\hline $\begin{array}{l}\text { Cellulose insulation, ceiling } \\
0.38 \mathrm{~m}(15.00 \mathrm{in.})\end{array}$ & - & - & $0.029 \mathrm{C}$ & 43. & 1382 \\
\hline $\begin{array}{l}\text { Studs }(2 \times 45), \text { walls }-8.89 \mathrm{~cm} \\
\quad(3.50 \text { in.) }\end{array}$ & & & 0.115 & 513. & 1382 \\
\hline Soil: under cravl space & $\alpha$ & $d$ & 0.87 & 2003 & 837. \\
\hline Soil, berm & $d$ & a & 1.30 & 2099 & 963. \\
\hline Plywood $-0.79 \mathrm{~cm}(0.313 \mathrm{in.})$ & $0.52^{\circ}$ & $d$ & 0.115 & 545 & d \\
\hline Asphalt shingles $-0.48 \mathrm{~cm}(0.188 \mathrm{in.})$ & $0.90^{b}$ & d & 0 & 1121 & d \\
\hline Hardwood (oak) $-1.91 \mathrm{~cm}(0.75 \mathrm{in.})$ & 0.490 & 0.90 & 0.177 & 753 & 2387. \\
\hline Subfloor $-1.91 \mathrm{~cm}(0.75 \mathrm{in.})$ & - & $d$ & 0.115 & 513 & 1382 \\
\hline Common red brick $-5.72 \mathrm{~cm}(2.25 \mathrm{in.})$ & $0.82^{b}$ & $d$ & 0.35 & 1970 & 837. \\
\hline Linoleum tile $-0.32 \mathrm{~cm}(0.125 \mathrm{in})$. & $0.71^{b}$ & $d$ & $d$ & d & $a$ \\
\hline Calotex (sheathing) & - & - & 0.055 & 288 & 1298. \\
\hline Concrete & - & $d$ & 0.935 & 2307 & 653. \\
\hline Fiber glass insulation & - & - & 0.042 & 21 & 712 \\
\hline Tar paper & - & - & 0 & $d$ & $d$ \\
\hline $\begin{aligned} \text { Ground albedo: } & \text { Unimproved ffelds }=0.23 \\
& \text { Gravel areas }=d\end{aligned}$ & & & & & \\
\hline \multicolumn{6}{|c|}{ aListed value is taken from Ref. 2, except as otherwise noted. } \\
\hline
\end{tabular}




\section{APPENDIX B \\ SENSOR LOCATION DIAGRAMS}

Figures B-2 to B-6 show the location of all house-specific sensors, symbols used in these figures are presented in Fig. B-1. Figure B-2 shows the location of interior and exterior thermocouples; heat flux meters, and pyranometers; Fig. B-3 gives the location of the ceiling, attic, and roof sensors. Figure B-4 diagrams the crawl space sensors, Fig. B-5 details the section rakes shown in Figs. B-2, and B-3, and Fig. B-6 illustrates the ground temperature rakes shown in Fig. B-4. 
FIGURE SYMBOLS

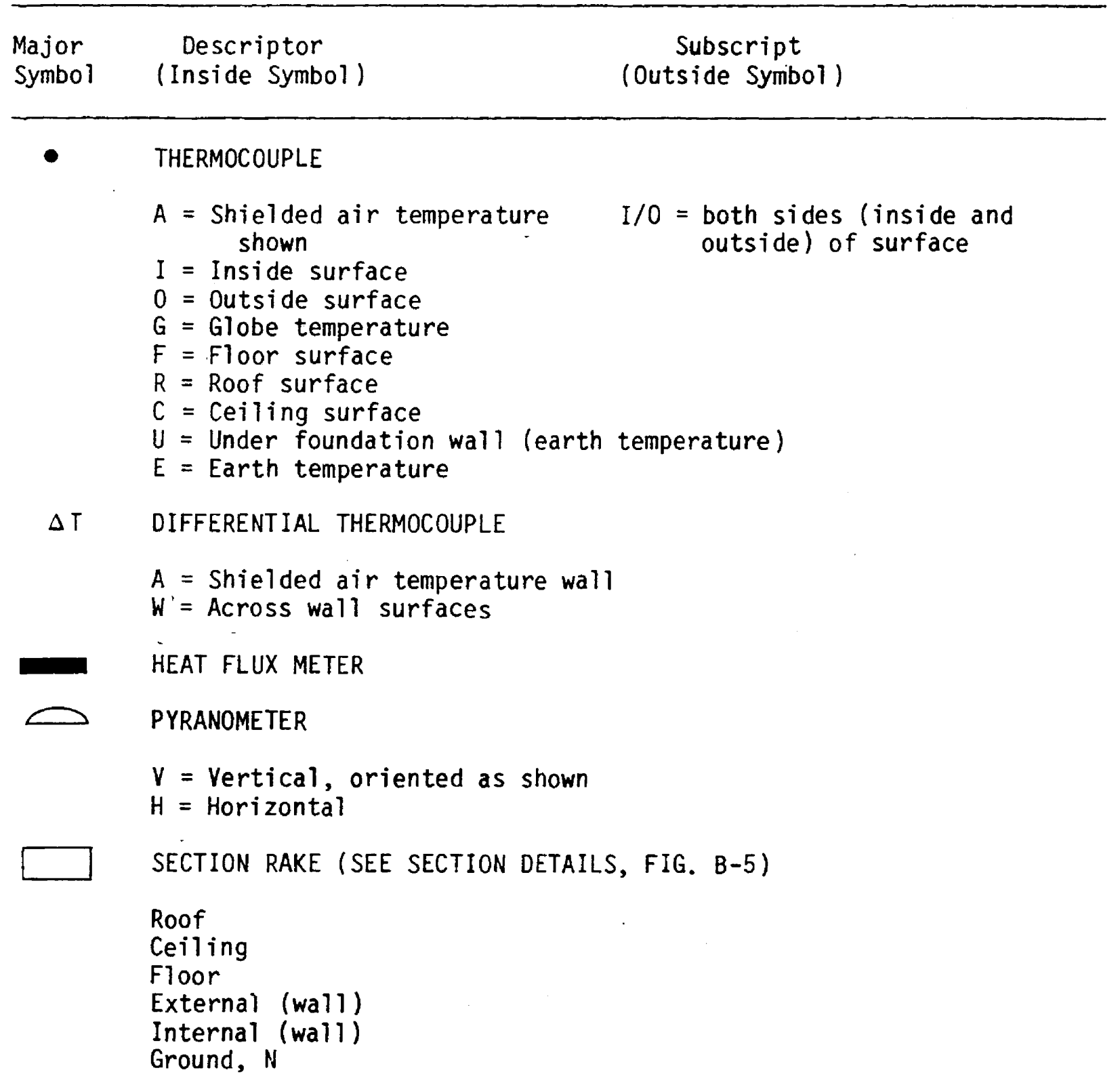

Fig. B-1. Figure symbols for Figs. B-2 through B-5. 


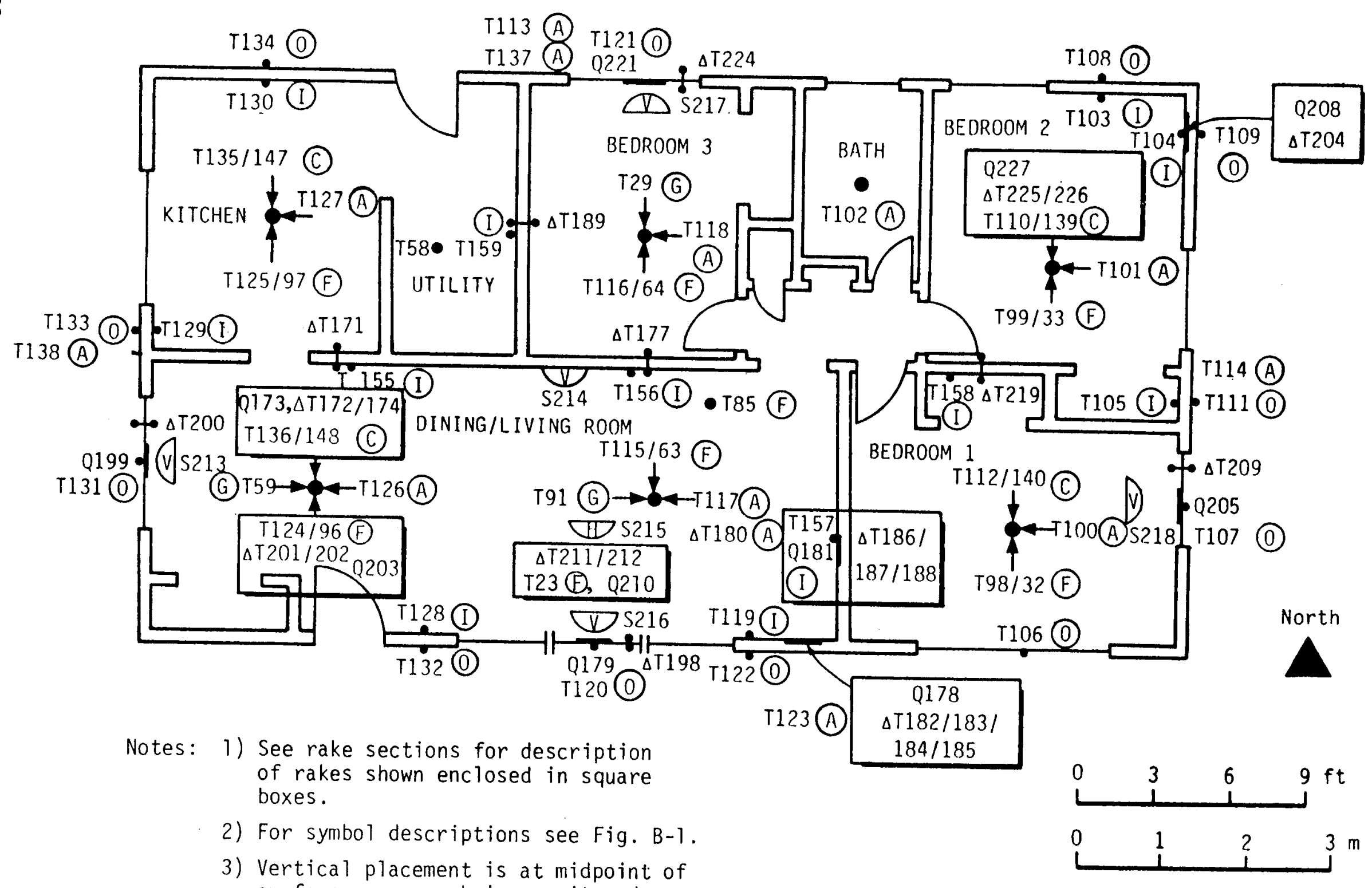

3) Vertical placement is at midpoint of surface or space being monitored.

Fig. B-2. Sensor locations--floor, walls, and ceiling. 


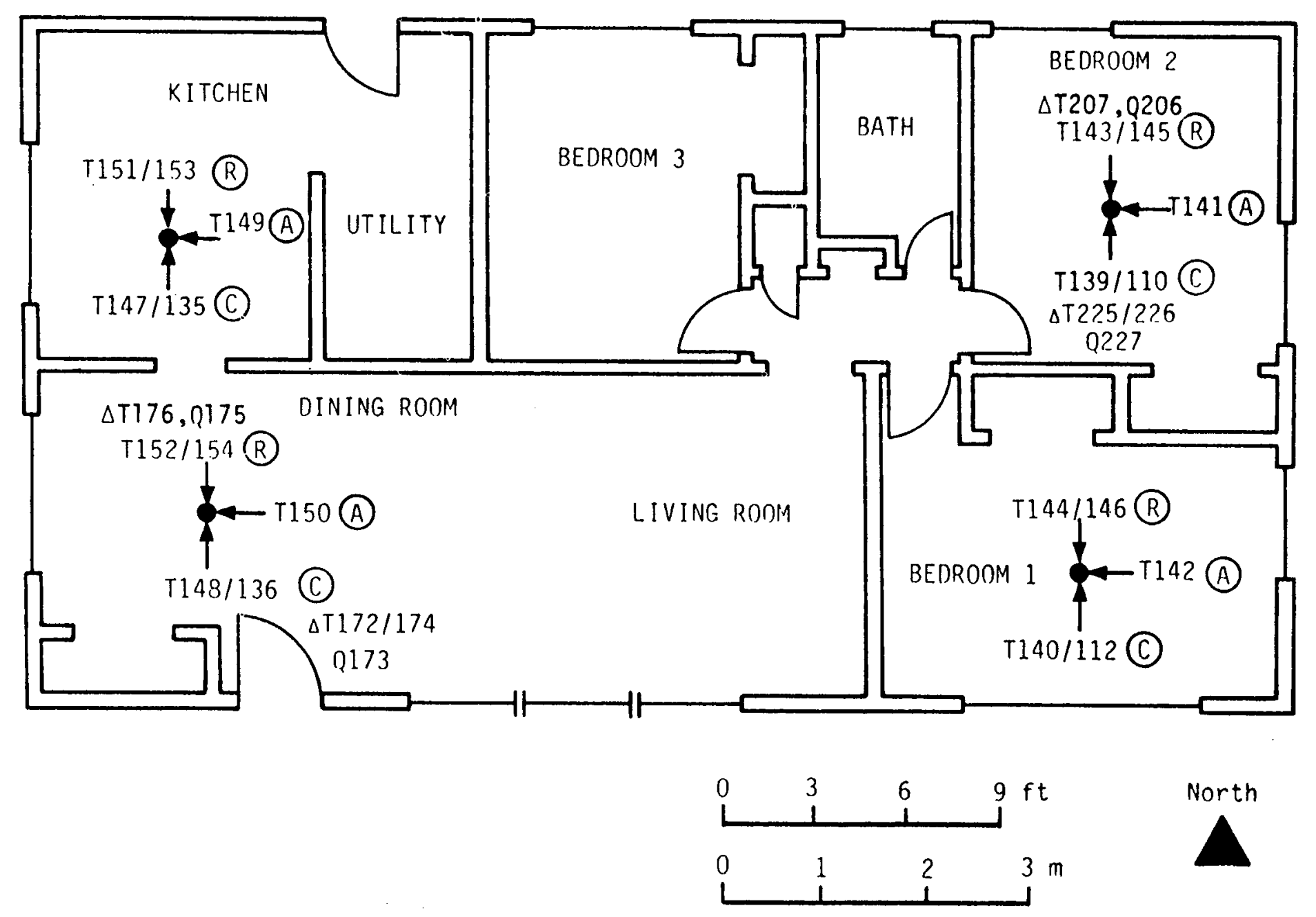

Fig. B-3. Sensor locations--ceiling, attic, and roof. 


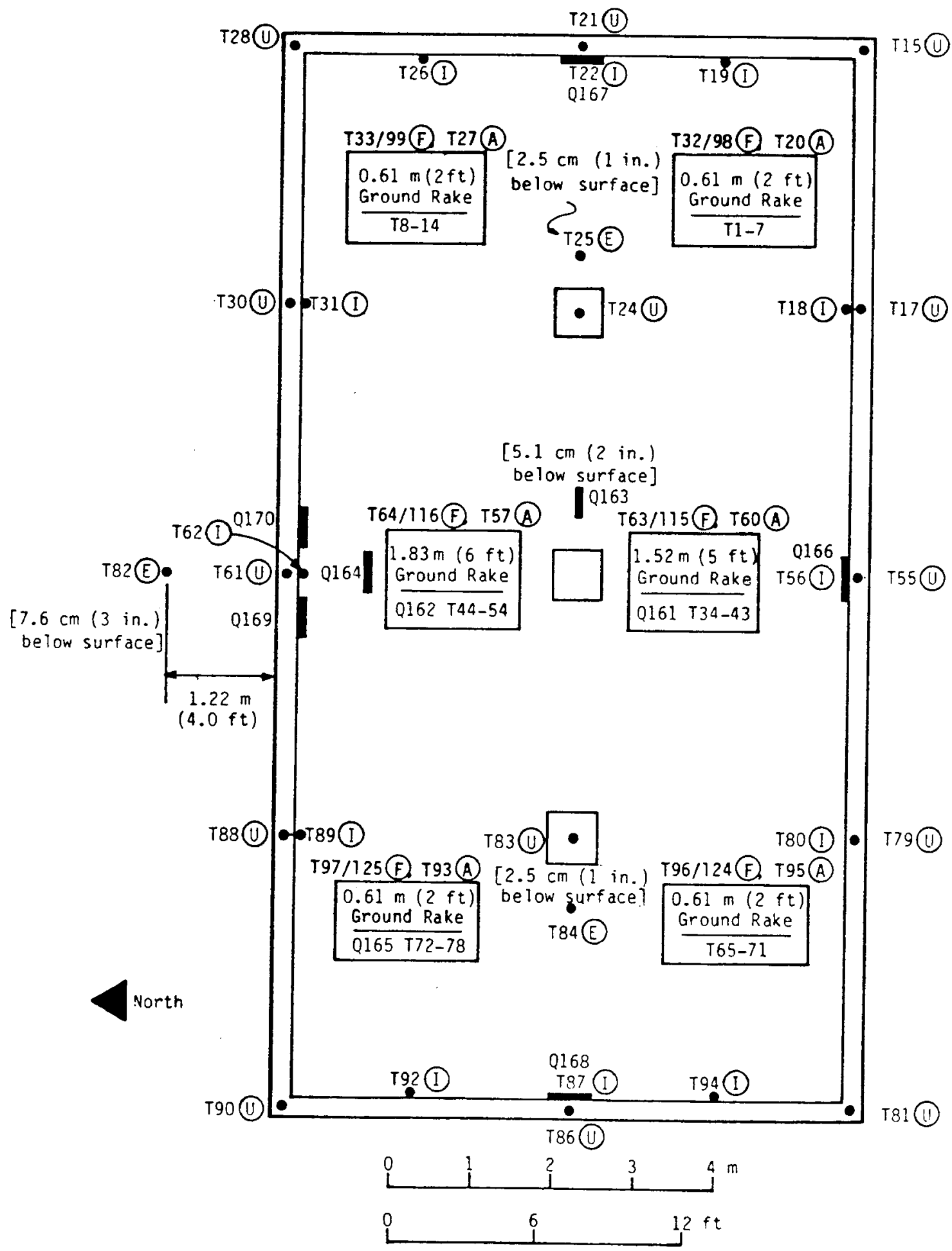

Fig. B-4. Sensor locations--crawl space. 


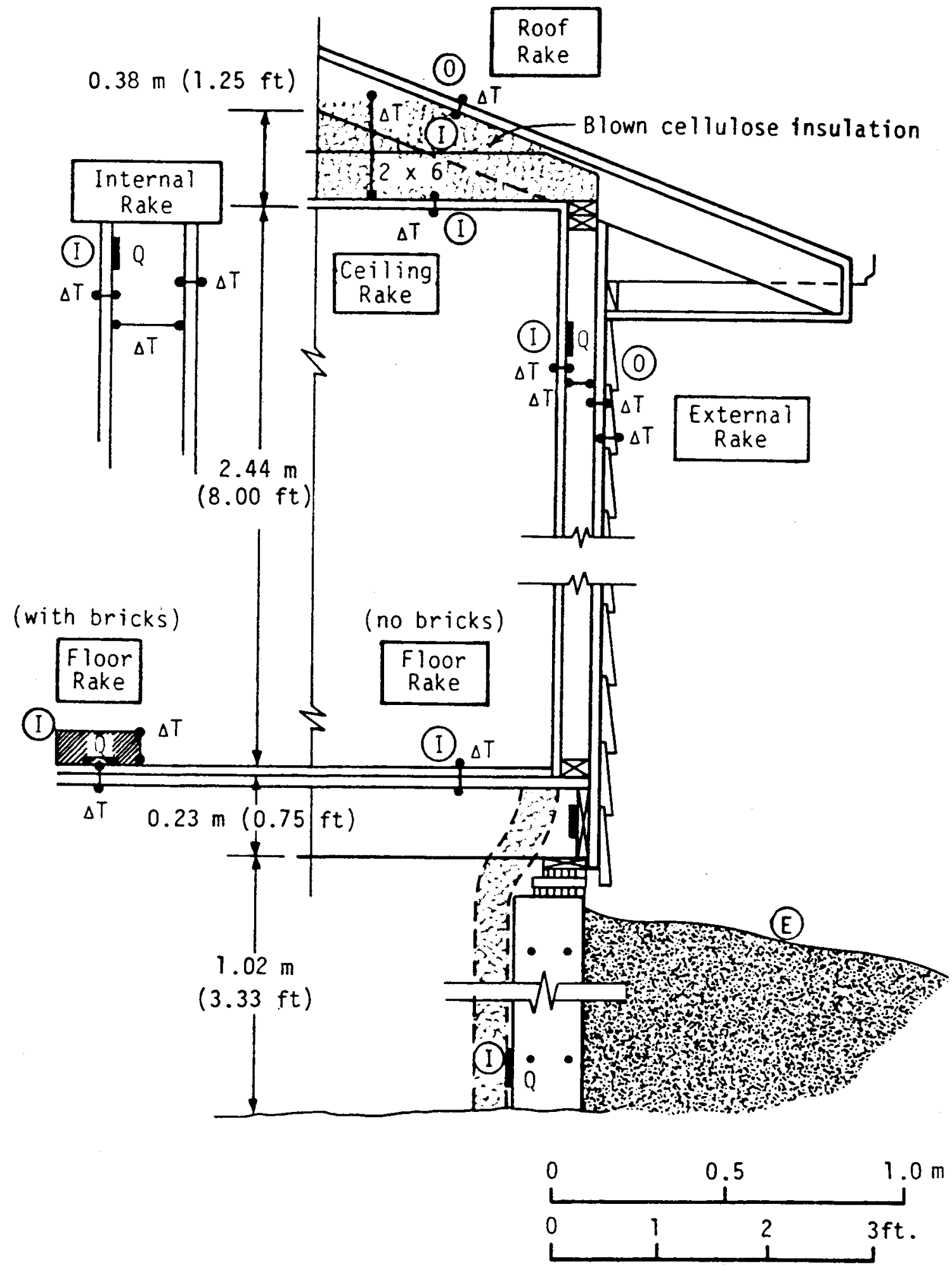

Fig. B-5. Sensor locations--thermocouple rakes. 


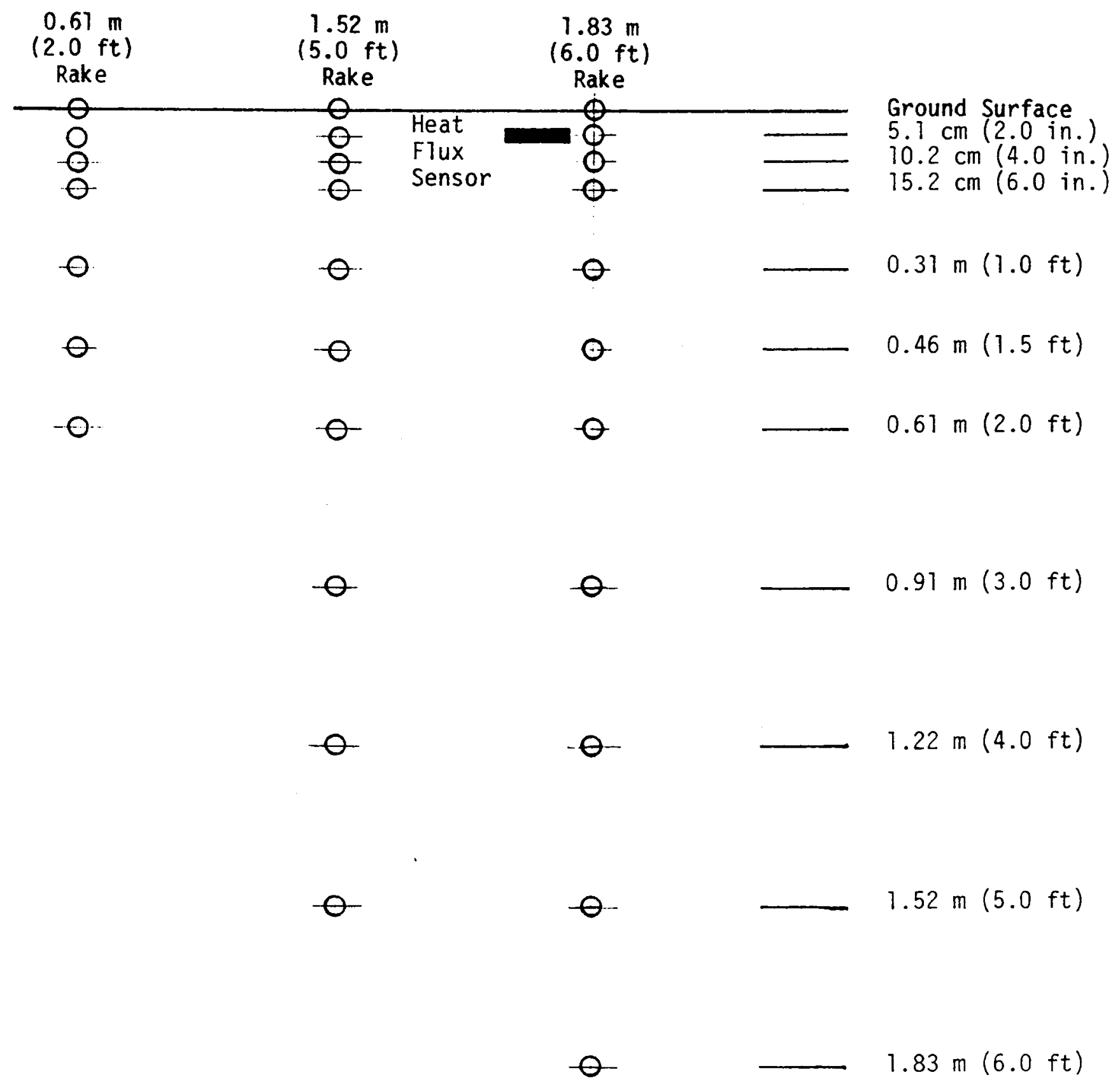

Fig. B-6. Ground thermocouple placement. 


\section{APPENDIX C \\ LIST OF DATA RECORDED HOURLY \\ (CHANNEL DIRECTORY)}


TEMPERATURE OF GROUND IN CRAWLSPACE SOUTH-EAST RARE, AT Z' OEPTH (F) *BAD*I TEMPERATURE OF GROUND IN CRAULSPACE SDUTH-EAST RAKE, AT 1.5' DEPTH (F)' TEMPERATURE OF GROUND IN CRAWLSPACE SDUTH-EAST RAKE, AT 1.0' DEPTH IFII TEMPERATURE OF GROUND IN CRAHLSPACE SOUTH-EAST RAKE, AT .5I DEPTH (F)I TEMPERATURE DF GRDUND IN CRAHLSPACE SOUTH-EAST RAKE, AT 4N DEPTH (F)/ TERPERATURE DF GROUND IN CRAWLSPACE SOUTH-EAST RAKE, AT 2 " DEPTH IFI/ TEMPERATURE OF GROUND IN CRAHLSPACE SOUTH-EAST RAKE, AT INSIDE SURFACE (FII TEMPERATURE OF GROUND IN CRAHLSPACE NORTH-EAST RAKE, AT 2 ' DEPTH (F)

TEMPERATURE DF GROUND IN CRALLSPACE NORTH-EAST RAKE, AT 1.5 D DIPTH IFII

TEMPERATURE DF GRDUND IN CRAHLSPACE NORTH-EAST RAKE, AT $1.00^{\circ}$ DEPTH (FI/ TEMPERATURE OF GROUND IN CRAHLSPACE NORTH-EAST RAKE, AT .5" DEPTH (FI/ TEMPERATURE OF GR OUND IN CRAHLSPACE NORTH-EAST RAKE, AT 4" DEPTH (FI/ TEMPERATURE OF GRDUND IN CRAHLSPACE NORTH-EAST RAKE, AT 2" OEPTH IFII TEMPERATURE DF GRDUND IN CRAWLSPACE NORTH-EAST RAKE, AT INSIDE SURFACE (FII TEMPERATURE OF FOUNDATION WALL SOUTH-EAST CORNER BOTTOM (FII

TEMPERATURE OF TEMPERATURE OF STANCARO SI (F) > JULIAN DAY $50 /$

TEMPERATURE OF FOUNDATION VALL SCUTH-EAST BOTTOM (FII

TEMPERATURE OF FOUNDATION WALL SOUTH-EAST MID-HETGHT INSIDE SURFACE OF CDNCRETE (FI/ TEMPERATURE OF FOUNDATION WALL EAST-SDUTH MID-HEIGHT INSIDE SURFACE OF CONCRETE (F)I TEMPERATURE OF AIR IN THE CRAULSPACE SOUTH-EAST HID-HEIGHT (F)

TEMPERATURE OF FOUNOITIJN WALL EAST-MIDOLE BOTTOR IFII

TEMPERATURE OF FOUNDATION WALL EAST-MIOJLE MID-HETGHT INSIDE SURFACE OF CONCRETE (FII TEMPERATURE OF FLOOR IN THE LIVINGROOM EAST-SOUTH ON INSIDE SURFACE (F) > JULIAN DAY BQI TEMPERATURE UNDERNEATH PILLAR EAST-MIDOLE (FI/

TEMPERATURE OF GR JUND IN CRAHLSPACE EAST OF EAST-MIDDLE PILLAR,AT 1" OEPTH (F)/ TEMPERATURE OF FOUNDATIJN VALL EAST-NORT4 MID-HEIGHT INSIDE SURFACE OF CONCRETE (F)I TEMPERATURE OF AIR IN THE CRAHLSPACE NORTH-EAST MID-HEIGHT (F)/ TEMDERATURE OF FOUNDATION WALL NORTH-EAST BOTTOM (F)'

TEMPERATURE OF GLOBE IN THE NORTHMIDDLE BEDFOOM MID-HEIGHT (F) > JULIAN DAY $75 /$ TEMPERATURE OF FOUNDATION WALL NORTH-EAST BOTTOM (F)'

TEMPERATURE OF FOUNDATION WALL NORTH-EAST MID-HEIGHT INSIDE SURFACE OF CONCRETE (FI, TEMPERATURE OF FLOOR IN THE SCUTHEAST BEDROOM MID-POINT ON OUTSIDE SURFACE (FI) TEMPERATURE OF FLDOR IN THE NDRTHEAST BEJPOOM MID-POINT ON CUTSIDE SURFACE (F)/ TEMPERATURE OF GROUND IN CRAHLSPACE SOUTH-MIDDLE RAKE, AT 5 ' DEPTH (F)/ TEMPERATURE OF GRDUND IN CRAULSPACE SOUTH-MIOOLE RAKE, AT 4. DEPTH (F)/ TEMPERATURE OF GRDUND IN CRAKLSPACE SOUTH-MIDDLE RAKE, AT 3' DEPTH IFII TEMPERATURE OF GR OUND IN CRAILSPACE SOUTH-MIDDLE RAKE, AT 2 ' OEPTH IFI/ TEMPEPATURE OF GROUND IN CRAWLSPACE SOJTH-MIODLE RAKE, IT $1.5^{\circ}$ DEPTH (F)I TEMPERATURE OF GRDUND IN CRAHLSPACE SOUTH-MIDDLE RAKE, AT 1 " DEPTH (F)/ TEMPERATURE OF GR OUND IN CRAHLSPACE SOUTH-MIDOLE RAKE, AT OM DEPTH IFI/ TEMPERATURE OF GRDUND IN CRAULSPACE SOUTH-MIDOLE RAKE, AT 4" DEPTH (F)/ TEMPERATURE OF GROUND IN CRAYLSPACE SOUTH-YIDOLE RAKE, AT 2" DEPTH IFII TEMPERATURE OF GROUND IN CRAHLSPACE SOUTH-MIDCLE RAKE, IT INSIDE SURFACE (FI/ TEMPERATUPE OF GROUND IN CRAWLSPACE NORTH-MIODLE RAKE, AT O' DEPTH (F)I TEMPERATURE DF GROUND IN CRAWLSPACE NORTH-MIDDLE RAKE, IT 5 D DEPTH (F)/ TEMPERATURE OF GROUND IN CRAULSPACE NORTH-MIDDLE RAKE, AT $4{ }^{\circ}$ DEPTH (F) TEMPERATURE OF GROUND IN CRAWLSPACE NCRTH MIODLE RAKE, AT 3' DEPTH (F)/ TEMPERATURE OF GROUND IN CRAHLSPACE NORTH-MIDDLE RAKE, AT 2 ' DEPTH IFII TEMPERATURE OF GROUND IN CRAWLSPACE NORTH-MIDDLE RAKE, AT 1.5 DEPTH (FII TEMPERATURE OF GR OUND IN CRAHLSPACE NORTH-MIDOLE RAKE, AT 1 CEPTH (F)/ TEMDERATURE OF GRDUND IN CRAHLSPACE NDRTH-MIDDLE RAKE, AT 6" OEPTH IFI/ TEMPERATURE DF GROUND IN CRAWLSPACE NORTH-MIDDLE RAKE, AT 4" DEPTH IFII TEMPERATURE DF GROUNC IN CRANLSPACE NORTHMMIOOLE RAKE, AT 2 "DEPTH (F)I TEMPERATURE OF GROIJND IN CRAWLSPACE NORTH-MIDDLE RAKE, AT INSIDE SURFACE (F)I TEMPERATURE OF FOUNDATION WALL SOUTH-MIOOLE BOTTDM (FI)

TEMPERATURE DF FOUNDATION WALL SOUTH-MIDDLE MID-HEIGHT INSIDE SURFACE OF CDNCRETE (FII TEMPERATURE OF AIR IN THE CRAHLSPACE NORTH-MIOOLE MID-HEIGHT (F)/ TEMPERATURE OF S2 STANDARD,>50;AIR IN THE UTILITY ROJM >120 (FS)/ TEMPERATURE OF GLOBE IN THE LIVINGRDOM WEST-MIODLE MID-HEIGHT (F), TEMPERATURE DF AIR IN THE CRAWLSPACE SJUTH-MIODLE MID-HEIGHT (FII TEMPERATURE OF FOUNDATION WALL NORTH-MIODLE BOTTOM (F)' TEMPERATURE OF FOUNDATION WALL NORTHMIJDLE MID-HEIGHT INSIDE SURFACE OF CONCRETE IFI/ TEMOERATUPE OF FLOOR IN THE LIVINGROOM EAST-MIDOLE ON OUTSIDE SURFACE (FI) TEMPERATURE OF FLOOR IN THE NORTHMIODLE BEDROOM MID-POINT ON DUTSIOE SURFACE (FI, 
T65 TEMPERATURE OF GROUND IN CRAHLSPACE SOUTH-NEST RAKE, AT Z" DEPTH (F)/

TE6 TEMPERATURE OF GR DUND IN CRAHLSPACE SOUTH-HEST RAKE, AT 1.51 OEPTH (F)

T67 TEMPERATURE OF GROUND IN CRAHLSPACE SOUTH-WEST RAKE, AT I' DEPTH IFII

T68 TEMPERATURE OF GROUND IN CRAHLSPACE SOUTH-HEST RAKE, AT 6\% DEPTH IFIM

T69 TEMPERATURE OF GROUND IN CRAHLSPACE SOUTH-WEST RAKE, AT 4\% DEPTH (F)/

T7O TEMPERATURE OF GROUND IN CRAHLSPACE SDUTH-HEST RAKE, AT 2W DEPTH TFII

T71 TEMPERATURE OF GROUND IN CRAWLSPACE SOUTH-WEST RAKE, AT INSIDE SURFACE (FI/

T72 TEMPERATURE OF GROUND IN CRAYLSPACE NORTH-WEST RAKE, AT 2' DEPTH (FII

T73 TEMPERATURE DF GROUND IN CRAWLSPACE NORTH-WEST RAKE, AT 1.5: DEPTH IFIT

T74 TEMPERATURE OF GROUND IN CRAHLSPACE NORTH-VEST RAKE, AT I" DEPTH (F)

T75 TEMPERATURE OF GRDUND IN CRAHLSPACE NJRTH-HEST RAKE, AT G" DEPTH (F)

T76 TEMPERATURE OF GROUNO IN CRAWLSPACE NORTH-WEST RAKE, AT 4\% DEPTH IFIT

T77 TEMPERATURE OF GRDUND IN CRAWLSPACE NORTH-WEST RAKE, AT 2" DEPTH (FII

T78 TEMPERATURE OF GROUND IN CRAWLSPACE NORTH-WEST RAKE, AT INSIDE SURFACE (FI)

T79 TEMPERATURE OF FOUNDATION WALL SOUTH-WEST BOTTOM (F)/

T80 TEMPERATURE OF FOUNDATION WALL SOUTH-WEST MID-HEIGHT INSIDE SURFACE OF CONCRETE (F)/

TB1 TEMPERATURE OF FDUNDATION VALL SDUTH-HEST-CORNER BOTTOM (FII

TB2 TEMPERATURE OF GROUND DUTSIOE 4' FROM NORTHMIDDLE BEDRODM, AT 3" DEPTH $>$ JULIAN DAY 75 TFII

T83 TEMPERATURE UNDERNEATH PILLAR WEST-MIDDLE (F)/

T84 TEMPERATURE OF GROUND IN CRAWLSPACE WEST OF WEST-MIDDLE PILLAR AT DEPTH OF I" (F)/

T85 TEMPERATURE OF FLOOR IN THE LIVINGROOH NORTH-EAST ON INSIOE SURFACE (F) $>$ JULIAN DAY BG/.

T86 TEMPERATURE OF FQUNDATION HALL HEST-MIDDLE BOTTOM (F)I

T87 TEMPERATURE OF FOUNDATION WALL WEST-MIODLE MID-HEIGHT INSIOE SURFACE OF CONCRETE (FII

TB8 TEMPERATURE OF FOUNDATION WALL NORTH-WEST BOTTOA (FII

T89 TEMPERATURE OF FDUNDATION WALL NORTH-HEST MID-HEIGHT IHSIDE SURFACE OF CDNCRETE (FII

T90 TEMPERATURE OF FOUNDATION WALL NORTH-WEST-CORNER BOTTOM IFII

T91 TERPERATURE OF GLOBE IN THE LIVINGROOM EAST-MIDDLE MID-HEIGHT (F)/

T92 TEMPERATURE OF FOUNDATION WALL WEST-NORTH MID-HEIGHT INSIOE SURFACE OF CONCRETE (FI/

I93 TEMPERATURE OF IIR IN THE CRAULSPACE NORTH-WEST MID-HEIGHT (F)!

T94 TEMPERATURE DF FOUNOATION WALL WEST-SOUTH MID-HEIGHT INSIDE SURFACE OF CONGRETE IFIT

T95 TEMPERATURE OF AIR IN THE CRAULSPACE SOUTH-YEST MID-HEIGHT (F)I

T96 TEMPERATURE OF FLODR IN THE LIVINGROOM WEST-MIDDLE DN OUTSIDE SURFACE OF WOOD (F)/

T97 TEMPERATURE OF FLDOR IN THE KITCHEN MIO-POINT ON OUTSIDE SURFACE (FII

T98 TEMPERATURE OF FLDOR IN THE SOUTHEAST BEOROOM MIO-POINT ON INSIDE SURFACE IFI,

T99 TEMPERATURE OF FLOOR IN THE NORTHEAST BEDROOM MID-POINT ON INSIOE SURFACE (FI/

T100 TEMPERATURE OF AIR IN THE SOUTHEAST BEORODM MID-POINT MID-HEIGHT (F)I

TIO1 TEMPERATURE DF AIR IN THE NORTHEAST BEDRTOM MID-POINT MID-HEIGHT (F)/

T1O2 TEMPERATURE OF AIR IN THE BATH MID-POINT MID-HEIGHT (F)/

T103 TEMPERATURE OF NORTH WALL IN THE NDRTHEAST BEDRDOM MIODLE-EAST ON INSIDE SURFACE IFI/

T104 TEMPERATURE OF EAST HALL IN THE NCRTHEAST BEDROOH HIOOLE-NORTH ON INSIDE SURFACE (F)/

TIO5 TEMPERATURE OF EAST WALL IN THE NORTHEAST BEDRDOM MIDOLE-SOUTH DN INSIDE SURFACE (FII

TIOS TEMPERATURE OF SOUTH GLAZING IN THE SOUTHEAST BEDRODM MIDMPOINT ON DUTSIDE SURFACE IFII

T107 TEMPERATURE OF EAST GLAZING IN THE SOUTHEAST BEDRDOM MID-POINT ON DUTSIDE SURFACE (F)

T108 TEMPERATURE DF NORTH HALL IN THE NORTHEAST BEOROOH MIDOLE-EAST ON OUTSIDE SURFACE (FII

T109 TEMPERATURE OF EAST WALL IN THE NORTHEAST BEDROOM MIDDLE-NORTH ON DUTSIDE SURFACE (FII

T110 TEMPEQATURE OF CEILING IN THE NORTHEAST BEDROOM MIO-POINT DN INSIOE SURFACE IFII

T111 TEMPERATURE OF EAST WALL IN THE NCRTHEAST BEDRDOM MIDDLE-SDUTH ON DUTSIDE SURFACE (FI'

T112 TEMPERATURE OF CEILING IN THE SOUTHEAST BEDROOM MID-POINT ON INSIDE SURFACE IFII

T113 TEYPEQATURE OF AIR IN THE OUTSIDE NDRTH-MIDDLE BOTTOM (F)'

T114 TEMPERATURE OF AIR IN THE OUTSIDE EAST-MIODLE MID-HEIGHT (F) \#BAD*I

T115 TEYPERATURE OF FLOQR IN THE LIVINGRDOH EAST-MIDDLE ON INSIDE SURFACE IFII

T116 TEMPERATURE OF FLOOR IN THE NORTHMIDDLE BEDRDOM MID-POINT ON INSIOE SURFACE (FI/

T117 TEMPERATURE OF ATR IN THE LIVINGROOM EAST-MIDDLE MID-HEIGHT (F)

T118 TEMOERATURE OF AIR IN THE NORTHMICOLE BEDRODK RID-POINT MIO-HEIGHT (F)

T119 TEMPERATURE OF SOUTH WALL IN THE LIVINGRDOM EAST-MIODLE ON INSIDE SURFACE (FII

T120 TEMPERATURE OF SOUTH GLAZING IN THE LIVINGROOM MID-POINT ON OUTSIDE SURFACE (F),

T121 TEMPERATURE OF NORTH GLAZING IN THE NORTHMIDDLE BEDRDOM MID-POTNT DN DUTSIDE SURFACE IF

T122 TEMPERATUPE OF SOUTH WALL IN THE LIVINGROOH EAST-MIDDLE ON OUTSIDE SURFACE (FII

T123 TEMPERATURE DF AIR IN THE QUTSIDE SOUTH-MIDDLE TOP NEAR OVERHANG (F)I

T124 TEMOERATURE OF FLOOR IN THE LIVINGROJM WEST-MIDDLE ON INSIDE SURFACE OF BRICK (F)/

TI25 TEMPERATURE OF FLOOR IN THE KITCHEN MID-POINT ON INSIDE SURFACE (FI/

T126 TEMPERATURE DF IIR IN THE LIVINGROON WEST-MIODLE (F)

TI27 TEMPERATURE DF IR IN THE KITCHEN MID-POINT IFIP

II28 TEMPERATURE OF SOUTH WALL IN THE LIVIVGRTOM WEST-MIDDLE ON INSIDE SURFACE (F)/ 
TI20 TEMPERATURE OF HEST HALL IN THE KITCHEN SOUTH-RIDOLE ON INSTDE SURFACE (FI,

T130 TEMPERATURE OF NIRTH YALL IN THE KITCHEY MIO-POINT DN INSIOE SURFACE IFII

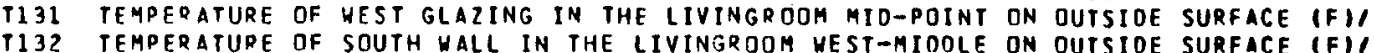

T133 TEMPERATURE OF WEST NALL IN THE KITCHEN SOUTH-MIDOLE ON OUTSIDE SURFACE (FI,

T134 TEMPERATURE OF NORTH HALL IN THE KITCHEN MIO-POINT ON OUTSTOE SURFACE (F)'

T135 TEMPERATUQE OF CEILING IN THE KITCHEN YID-POINT ON INSIDE SURFACE (FII

T136 TEMPERATURE OF CEILING IN THE LIVINGROIM HEST-MIDDLE ON INSIDE SURFACE IFI/

T137 TEMPERATURE OF AIR IN THE OUTSIDE NORTH-MIDDLE TOP NE AR OVERHANG IFII

T138 TEYPERATURE OF AIR IN THE OUTSIDE EAST-MIODLE HIDOLE OF WEST WALL (F)/

T139 TEMPERATURE OF CEILING IN THE NDRTHEAST GE ORDOM MID-POINT ON OUTSIDE SURFACE (FI)

T140 TEMDERATURE OF CEILING IN THE SOUTHEAST BEDROOH MIO-POINT ON OUT
T141 TEMPERATURE OF AIR IN THE ATTIC NORTH-EAST MIDOLE-HEIGHT IFI,:

T142 TEMPERATURE OF AIR IN THE ATTIC SOUTH-EAST MIDDLE-HEIGHT IFI

T143 TEMPERATURE OF NORTH ROOF IN THE ATTIC NORTH-EAST ON INSIDE SURFACE IFII

1145 TEMPERATURE OF SOUTH RODF IN THE ATTC NORTH-EAST ON INSIOE SURFACEE TFI

T146 TEMPERATURE OF SOUTH ROOF IN THE ATTIC SOUTH-EAST ON DUTSIDE SURFACE IFI

T147 TEMPEQATURE OF CEILING IN THE KITCHEN MID-POINT ON OUTSIOE SURFACE IFII

T148 TEMPERATURE OF CEILING IN THE LIVINGROOH YEST-MIDDLE ON DUTSIDE SURFACE IFI

149

1150

TEMOERATURE OF AIR IN THE ATTIC NORTH-WEST MIDDLE-HEIGHT IFI'

TEMPERATURE OF NORTH ROOF IN THE ATTIC NDRTH-HEST DN INSIDE SURFACE IFI/

TEMPERATURE OF SOUTH ROOF IN THE ITIIC SOUTH-UEST ON INSIDE SURFACE (FII

TEMPERATURE OF NORTH ROOF IN THE ATTIC NORTH-NEST ON OUTSIDE SURFACE (F)

TEMPERATURE OF SOUTH ROOF IN THE ATTIC SOUTH-WEST ON OUTSIDE SURFACE (F)

TEMPERATURE OF NORTH WALL IN THE LIVINGRODH NEST-MIODLE ON INSIDE SURFACE IFI)

TEMPERATURE OF NORTH WALL IN THE LIVINGROOM EAST-MIODLE ON INSTOE SURFACE (F)

TEMPERATURE OF EAST WALL IN THE LIVINGROOM MID-POINT ON INSIDE SURFACE (F)

TEMPERATURE OF NOR.TH HALL IN THE SOUTHEAST BEDROOM VEST-MIDDLE ON INSIDE SURFACE IFI

TEMDERATURE OF EAST WALL IN THE UTILITYROOM MIO-POINT ON INSIDE SURFACE (FI,

TEMPERATURE OF ICE BATH REFERENCE (F)

THERMAL FLUX INTO THE GROUND IN CRAYLSPACE NDRTH-MIDOLE AT DEPTH OF 2" (BTUIFT2-HRI'

THERMAL FLUX INTO THE GROUND IN CRAHLSPACE MID-POINT AT DEPTH OF 2" (BTUIFT2-HI).

THERMAL FLUX INTD THE GROUND IN CRAHLSPACE NORTH-MIDOLE-NORTH AT DEPTH OF 2" 18 TUN

0157

0168

0169

HERMAL FLUX INTO THE FDUNDATION WALL IN THE CRAYLSPACE SOUTH-MIDDLE MIO-HEIGHT INSTDE SURFACE OF CONCRETE IBTUIFT2-HRII

THERMAL FLUX INTO THE FOUNDATION WALL IN THE CRAHESPACE EAST-MIDDLE MID-HEIGHT INSIDE SURFACE DF CONCRETE TBTUIFT2-HRII

THERMAL FLUX INTO THE FOUNDATION HALL IN THE CRANLSPACE MEST-MIDDLE MIO-HEIGHT INSIDE SURFACE OF CONCRETE CBTUIFT2-HRII

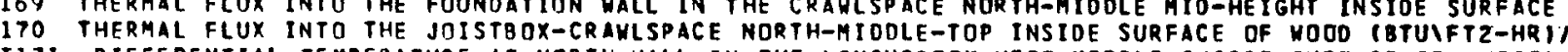

DTI71 DIFFERENTIAL TEMPERATURE AT NORTM HALL IN THE IIVINGROOM VEST-MIODLE INSIDE SURFACE TJ OUTSIOE SURFACE IFII

DIFFERENTIAL TEMPERATUPE AT CEILING IN THE LIVINGRODM NEST-MIODLE INSIDE TO OUTSIDE OF GYPSUM (FII

THERMAL FLUX INTO THE CEILING IN THE LIVINGROOM MEST-MIDDLE BURIED BETHEEN GYPSUM AND CELLULOSE IBTUIFT2-HRII

DT174 DIFFERENTIAL TEMPERATURE AT CEILING IY THE LIVINGROOM NEST-MIDDLE INSIDE TO OUTSIDE OF CELLULOSE IFIS

作

OTI77 DIFFERENTIAL TEMPERATURE AT NORTH YALL IN THE LIVINGRDOM EAST-MIDOLE INSIDE SURFACE TO OUTSIDE SURFACE IFI

OI78 THERMAL FLUX INTO THE SOUTH YALL IN THE LIVINGROOA EAST-MIODLE BURIED BETUEEN GYPSUM AND CELLULOSE (BTUIFT2-HI)

Q179 THEQMAL FLUX INTO THE SOUTH GLAZING IN THE LIVINGROOM MID-POINT ON INSIDE SURFACE (BTUIFT2-HRII

DT180 DIFFERENTIAL TEMPERATURE AT AIR IN THE LIVINGROOM EAST-MIDOLE CEILING IN THE FLOOR (F)/

0181 THERMAL FLUX INTO THE EAST MALL IN THE LIYINGROOM MID-POINT BURIED BETYFEN GYPSUM AND GELLULOSE (BTUIFZ-HII

OT182 OIFFERENTIAL TEMPERATURE AT SOUTH WALL IN THE LIVINGRODM EAST-MIDDLE INSIDE TO OUTSIDE OF GYPSUN IFIT

DT 3 DIFFERENTAL TEAPEPATURE AT SOUTH WALL IN THE LIVINGROOM EAST-MIDDLE INSIDE TO OUTSIDE OF CELLULOSE IFII

OT

DT186 DIFFERENTIAL REMPERATRE AT SOUTH HALL IN THE LIVINGRDOM EAST-MIDDLE INSIOE TO DUTSIOE OF SIOING IFII

OT1B? DIFFEREMTIAL TEMPERATURE AT EAST WALL IN THE LIVINGROOM MID-POINT INSIOE TO OUTSIOE OF GYPSUH IFII

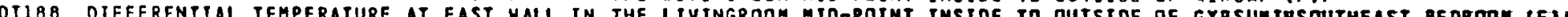

DIIB DIFFERENIAL TEMPERATURE AT EAST WALL IN THE UTILITYROOM MID-POINT INSIDE SURFACE TO OUTSIDE SURFACE (F),

VI90 REFERENCE YOLTAGE. AG-AGOX BATTERYTDIVIDER=G MY CMVII

WIO1 WATTMETER FOR HOUSE TOTAL POVER (WATTSII

HIQ2 WATTMETER FOR HOIISE TOTAL IIOV POMER (HATTSI, 
HI93 WATTMETER FOR KITCHEN HEATER POWER (WATTSI,

W194 WATTMETER FOR LIVING RDOM HEATER POWER (WATTSII

(165 WATTMETER FOR NORTH GEDRDOHS HEATER POHER (WATTSI)

W196 WATTMETER FOR SOUTH-EAST BEOROOM HEATER POWER (WATTSII'

W97 WaTrMETER FOR UTILITY RDOH DEVICES AFTER DAY 120 [HATTS)

OT198 DIFFERENTIAL TEMPERATURE AT SOUTH GLAZING IN THE LIVINGROOM MIO-POINT INSIDE SURFACE TO DUTSIDE SURFACE IFII

O190 THERMAL FLUX INTO THE WEST GLAZING IN THE LIVINGROOM MID-POINT ON INSIDE SURFACE (BTUIFT2-HRII

DIFFERENTIAL TEMPERATURE AT WEST GLAZING IN THE LIVINGROOM MIO-POINT INSIDE SURFACE TO OUTSIDE SURFACE IFII

DI202 DIFFERENTIAL TEMPERATURE AT FIOOR IN THE IVINGROOH UEST-MIODLE INSIOE TO OUTSIOE OF WODD TFIT

0203 THERMAL FLUX INTO THE FLOOR IN THE LIVINGROOH MEST-MIODLE OURIED BETHEEH ORICK AND HOOD IFIU

OT204 OIFFERENTIAL TEMPERATURE AT EAST W:LL IN THE NORTHEAST BEDROOM NORTH-MIDDLE INSIDE TD DUTSIDE OF CELLULOSE (F)/

O205 THERMAL FLUX INTO THE EAST GLAZING IN THE SOUTHEAST BEOROOH MID-POINT ON INSIDE SURFACE (BTUIFT2-HRI)

Q206 THERMAL FLUX INTO THE ROOF IN THE ATTIC NORTH-EAST ON INSIDE SURFACE (BTUIFT2-HR)/

DT 207 DIFFERENTIAL TEMPERATURE AT ROOF IN THE ATTIC NORTH-EAST INSIDE TO DUTSIDE SURFACE (F)

Q208 THERMAL TLUX INTO THE EAST HALL IN THE NORTHEAST BEDROOM NORTH-MIDOLE BURIED BETHEEN GYPSUM ANO CELLULOSE IBTUIFT2-HR

DT209 DIFFERENTIAL TEMPERATURE AI EAST GLAZING IN THE SOUTHEAST BEDROOM MIO-POINT ON OUTSIDE SURFACE IBTUIFT2-HRI,

0210 THERMAL FLUX INTO THE FLOOR IN THE LIVINGROOM SOUTH-EAST BURIEO BETWEEN WOOD ANO BRICK (BTUIFT2-HRII

OT211 DIFFERENTIAL TEMPERATURE AT FLODR IN THE LIIINGROOM SOUTH-EAST INSTOE TO OUTSIDE OF WOOO (BTUIFT2-HRII

OT212 DIFFERENTIAL TE HPERATURE AT FLOOR IN THE LIVINGROOH SOUTH-EAST INSIOE TO OUTSIDE OF BRICK (BTUIFTR

S213 GLOBAL SOLAR IRRADIANCE IT HEST GLAZING IN THE LIVINGROOM MID-POINT VERTICAL TRANSMITTED (HIMZI

S214 GLOBAL SOLAR IRRAOIANCE AT NORTH WALL IN THE LIVINGROOH EAST-HIDOLE VERTICAL INCIDENT (WIMZ)

S216 GLOBAL SOLAR IRRADIANCE AT SOUTH GN THE LIVINGROOM SOUTH-AIDOLE HORIZONTAL INCIDENT TWIGLIT

S217 GLOBAL SOLAR IRRADIANCE AT NORTH GLAZIVG IN THE NORTHMIODLE BEDROOA MID-POINT VERTICAL TRANSMITTED (WIMZS

S218 GLOBAL SOLAR IRRADIANCE AT EAST GLAZING IN THE SOUTHEAST BEDROOM MID-POINT VERTICAL TRANSMITIED IMIMZII

DI219 OIFFERENTIAL TEMPERATURE AT NORTH WALL IN THE SOUTHEAST BEDROOM WEST-MIDOLE INSIOE SURFACE TO OUTSIDE SURFACE IFIT--

220 VOLTAGE REFERENCE- AG-AGOX BATTERY= 1.6V [V]I

Q221 THERMAL FLUX INTO THE NORTH GLAZING IN THE NORTHMIOOLE BEDROOM MID-POINT UN INSIDE SURFACE (BTUIFT2-HR),

V222 VOL TAGE REFERENCE- SHORTED CHANNEL ZERO OHAS TVII

OT224 OIFFERENTIAL TEMPERATURE AT NORTH GLAZING IN THE NORTHMIDDLE BEDROOM MID-POLNT INSIDE TO OUTSIOE SURFACE (FI

OIZ25 OIFFERENTIAL TEMPERATURE AT CEILING IN THE NORTHEAST BEDROOM MIDOPOINT INSIOE TO OUTSIOE OF CELLULLSE IFII

0227 THERMAL FLUX INTO THE CEILING IN THE NORTHERST BEDRDOM HID-POINT BURIED BETHEEN GYPSUM AND CELLULOSE (BTUIFT 2-HRII

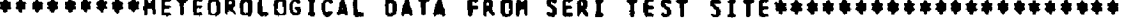

GLOGAL SOLAR IRRMOIANCE HORIIONTAL (WIMZI)

GLOBAL SOLAR IRRADIANCE AT 4ODEG TILT IYIMZI/

GLOBAL SOLAR IRRADIANCE VERTICAL SOUTH AT IRL STATION IWIM2II

GLOBAL SOLAR IRRAOIANCE VERTICAL SOUTH AT VALIDATION TEST CELL (WIMZI,

NORMAL BEAM NIP (WIAZIO

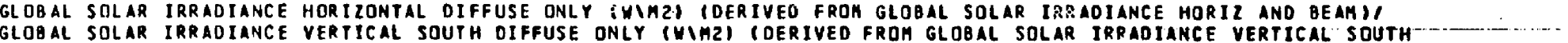
AND BEAH DATAII

GLOBAL SOLAR IRRADIANCE VERTICAL SOUTH SKY OIFFUSE ONLY (WIMZ) (DERIVED FROM GLOBAL SOLAR IRRADIANCE VERTICAL SOUTH, GEAH, AND ALBEDO DATAY

GLOBAL SOLAR IRRADIANCE 40 DEG. TILT DIFFUSE ONLY (WIMZ) (DERIVED FROM GLOEAL SOLAR IRRADIANCE $400 E G$ AND BEAM DATAI'

GLOBAL SOLAR IRRADIANCE 40 OEg TIL OIFFUSE SKY ONLY (WIMZI IOERIVEO FROH GLOBAL SOLAR IRRADTANCE qODEG TILT BEAM, ANO ALBEDO DATAI

GLOBAL SOLAR IRRAOIANCE AT IBOOEG TILT (WIMLI'

ALBEDO OF GRASS FIELOS (DERTVED
UIND SPEED AT IOH HEIGHT (MIS)'

WINO NOR THER COMPONENT IOH IMISI/

GIND EASTERM COMPONENT IOH (MISI

WIND SPEEO IT $2 \mathrm{H}$ HEIGHT (MISII

VINO NORTHERN COMPONENT $2 M$ (MISI,

WIND EASTERN COMPONENT $2 M$ IMISI'

ATMOSPHERIC PRESSURE (MILLIBARSI,

SEA LEVEL ATMOSPHERIC PRESSURE (MB) IDERIVEO FROH STATION PRESSUREOI

HELATIVE HUHIOITY $(2) 1$ 


\begin{abstract}
SKY INFRIRED FLUX (BTUIFTZ-HR)'
DEUPOINT TERPERATURE (F) IOERIVED AS IN ASHRAETT, CHAPS,FROM RELATIVE HUMIDITY AND PRESSUREI
\end{abstract}

SKY TEMPERATURE (F) (DERIVED FROM SKY INFRARED FLUX AND AMBIENT TEMPERATUREI) 
Printed in the United States of America Available from

National Technica! Information Service

US Department of Commerce

5285 Port Royal Road

Springfield, VA 22161

Microfiche (A01)

NTIS NTIS NTIS NTIS

Page Range Price Code

$001025 \quad A 02$

026-050 A03

$051.075 \quad$ A04

076-100 A05

101-125 A06

Page Range Price Code

151.175

176-200

$201-225$

226-250

251.275

$126 \cdot 150$

A06
A07

276.300

A08
A09

Page Range Price Code

NTIS
Page Range
Price Code

$301 \cdot 32$

A 14

$451.475 \quad 420$

$476.500 \quad A 21$

$351-375$

376-400

401.425

A 16

501.525

$526-550$

$551-575$

A 12

$426-450$

$576.600 \quad$ A25

601-up* A99

- Contact NTIS for a price quote. 